\title{
Analitik Hiyerarşi Süreci Kullanılarak Kişi Takip Cihazı Seçimi
}

\author{
Bedreddin Ali AKÇA ${ }^{1}$, Ahmet DOĞAN ${ }^{2}$, Uğur ÖZCAN ${ }^{3}$ \\ ${ }^{1}$ Yönetim Bilișim Sistemleri, Bilișim Enstitüsü, Gazi Üniversitesi, Ankara, Türkiye \\ ${ }^{2}$ Yönetim Bilişim Sistemleri, IÏBF, Osmaniye Korkut Ata Üniversitesi, Osmaniye, Türkiye \\ ${ }^{3}$ Endüstri Mühendisliği, Mühendislik Fakültesi, Gazi Üniversitesi, Ankara, Türkiye \\ bedir.akca@gmail.com, ahmetdogan@osmaniye.edu.tr, uozcan@gazi.edu.tr \\ (Geliş/Received: 23.09.2014; Kabul/Accepted: 20.01.2015) \\ DOI: $10.17671 / \mathrm{btd} .73079$
}

\begin{abstract}
Özet - Son yıllarda teknolojinin değişim ve gelişim hızına paralel olarak ortaya çıkan kişi takip cihazları insanların sevdikleriyle iletişimini koparmamak adına büyük önem arz etmektedir. Değer verilen her şeyin ne zaman, nerede olduğunun tespit edilmesi için geliştirilmiş ileri teknoloji ürünü olan bu cihazlar günümüzde daha yaygın kullanılmaya başlanılmıştır. Bu çalışmada, mevcut pazarda yer alan kişi takip cihazları, piyasa özellikleri dikkate alınarak incelenmiştir. Belirli özelliklere sahip beș adet kişi takip cihazı ve on adet seçim kriteri ele alınmıștır. Alanında uzman üç karar vericiye anket soruları uygulanmıştır. Böylelikle, kriterlerin ikili karşılaştırma matrislerinde objektif değerler elde edilmesi sağlanmıştır. Çalışmada, kamu ve özel sektörde grup karar alma problemlerinde kullanılan ve çok kriterli bir karar verme yaklaşımı olan Analitik Hiyerarși Süreci (AHP) ile kiși takip cihazları karșılaștırmalı olarak değerlendirilerek en iyi kişi takip cihazı alternatifi tespit edilmiştir. Verilen değerler kişiden kişiye değişebileceği için çıkacak sonucu doğrudan etkileyecektir. Farklı karar vericilerin verecekleri cevaplar sonucun farklı çıkmasına neden olabilir.
\end{abstract}

Anahtar Kelimeler - Kişi Takip, Kişi Takip Cihazı, Analitik Hiyerarşi Süreci, Çok Kriterli Karar Verme

\section{Person Tracking Device Selection Using Analytic Hierarchy Process}

\begin{abstract}
In recent years, the person tracking devices, which emerged in parallel to the speed of change and development of technology, are of great importance in people's ability to keep in touch with their loved ones. Developed to determine when and where every valuable thing is, these state-of-the-art advance technology devices are more commonly used nowadays. In this study, the person tracking devices in the existing market are examined in consideration with their market characteristics. Five person tracking device with certain features and ten selection criteria are considered. A questionnaire is applied to three experts in the field. Thus, an objective evaluation is obtained in the values of pairwise comparison matrix. In the study, the Analytical Hierarchy Process (AHP)-a multi-criteria decision making approach which is applied to decision making problems in public and private sectors- is used in the evaluation of person tracking devices in a comparative way and the best person tracking device alternative is determined. Because the values are different from person to person, it directly affects the outcome. The responses of different professionals may cause different consequences. Five person tracking device with certain features and ten selection criteria are considered. A questionnaire is applied to three experts in the field.
\end{abstract}

Keywords- Person Tracking, Person Tracking Device, Analytic Hierarchy Process, Multi-Criteria Decision Making

\section{GIIRIS (INTRODUCTION)}

Herhangi bir marka/model Kişi Takip Cihazına neden ihtiyaç duyulmaktadır? Aldatılma düşüncesi, merak etme hissi, her şeyi kontrol etme isteği ve daha birçok şey buna sebep olarak gösterilebilir. İnsanın doğasında var olan bu gibi faktörler negatif düşüncelerden veya zihinde yer eden olumsuz anilardan kaynaklanabilmektedir. $\mathrm{Bu}$ açıdan bakıldı ğında kişi takip cihazının gerekli olmadığı düşünülebilir. Ancak başka bir açıdan değerlendirdiğimizde kişi takip cihazının birçok avantajının olduğunu söylemek mümkündür. Örneğin sağlık alanı düşünüldüğünde, Alzheimer hastası olan bir kişinin hastalığın sebep olduğu nedenlerden ötürü nerede olduğunun bilinmesi gerekebilir. Çünkü Alzheimer hastası olan bir kişinin hastalı̆̆ın ilerleyen süreçlerinde oturdukları evlerinin adreslerini bile hatırlayamamaları ve bu yüzden kaybolma risklerinin yüksek olması, bu gibi durumlarda riskleri ortadan kaldırmak için hastaların 
bulundukları yerin konumuna ulaşılmak istenmesi, hasta aileleri düşünüldüğünde kişi takip cihazının önemini ortaya koymaktadır. Bununla birlikte kişi takip cihazlarının çocukların kaybolma/kaçırılma riskine karşı nerede olduklarının ve istenilen zamanda konumlarının bilinmesi gibi durumlarda aileler açısından büyük avantajlar sağladığı söylenebilir.

Çok kriterli karar verme (ÇKKV) ve Analitik Hiyerarşi Sürecine geçmeden önce karar vermeye değinmenin faydalı olabileceği düşünülmektedir. Literatürde karar vermenin farklı yönlerine vurgu yapılarak çeşitli tanımlamalara yer verilmiştir. Bu tanımlamalardan bazılarına değinmek gerekirse; karar verme, her yönetim düzeyinde sonuçlandırılması zorunlu olan bir veya bir dizi sorunun tüm boyutlarıla değerlendirilerek en uygun sonucu verebileceği saptanan seçenek veya seçeneklerin belirlenmesi [1], başka bir tanımda, amaca ulaşmada değişik davranışlar içinden etken olanın seçilmesi işlemi olarak tanımlanmaktadır [2]. Bir başka tanımda ise, Belirli bir amaca ulaşmak için değişik alternatiflerin belirlenmesi ve bunların içinden en etkilisinin seçilmesi işlemi olarak tanımlanmaktadır [3]. Son olarak ise mevcut tüm alternatifler arasından amaç veya amaçlara en uygun ve mümkün olan alternatiflerin bir veya birkaçını seçme süreci olarak ve [4], Alternatif hareket tarzlarının çevresel faktörlerle birlikte geliştirilip değerlendirilmesi sonunda, birinin rasyonel bir davranış olarak seçilmesidir [5].

Çok kriterli karar verme (ÇKKV) yöntemleri ise;1960'lı yıllarda, karar verme işlemine yardımcı olacak bir takım araçların gerekli görülmesiyle geliştirilmeye başlanmıştır. ÇKKV bilim alanında, iş dünyasında, Devletlerde ve mühendislik alanında karar verme metodolojisinde kullanılan en yaygın yöntemlerdir. ÇKKV yöntemleri karar verme sürecinde karar vericiler tarafından alınacak kararların kalitesini geliştirmek için, karar vericilerin daha açık ve anlaşılır, daha mantıklı ve daha etkili kararlar vermelerine yardımcı olmaktadır. ÇKKV yöntemlerinin bazı uygulama alanları, esnek üretim sistemleri, plan/düzenlem (layout) dizaynı, üretim sistemleri entegrasyonu ve teknoloji yatırım kararlarının değerlendirilmesi alanlarıdır [6].

ÇKKV yöntemlerinden biri olan Analitik Hiyerarşi Süreci (AHP): AHP son 20 yıldır çok kriterli karar alma ile ilgili uygulamaların neredeyse tamamında çok geniş ve yaygın bir şekilde kullanılmıştır (7). Saaty tarafından geliştirilen ilk çok kriterli karar alma yöntemidir. Karar en üstten en alta doğru hiyerarşik olarak bölünerek problem yapılandırılır. AHP'de en üst kademede amaç yer alır, orta kademede kriter ve alt kriterler, hiyerarşinin en alt kademesinde ise alternatifler yer alır. Uzman ve karar vericilerden elde edilen girdilerle, ikili karşılaştırma yapılarak en yüksek skora göre alternatifler sıralanır ve en iyi alternatif seçilir [8]. AHP, öğeleri arasında karmaşık ilişkiler sergileyen sistemlere ait karar problemlerinde; sistemi alt sistemleriyle ilişskili, hiyerarşik bir yapıda oldukça basitleştirerek ifade edip, sezgisel ve mantıksal düşünceyle irdeleyebilen bir yaklaşımdır [9]. Bundan dolayı karar vericiler tarafindan kolay anlaşılması sebebiyle oldukça yaygın bir şekilde birçok alanda kullanılmaktadır.

Analitik Hiyerarşi Süreci yönteminin bazı uygulama alanları, personel seçimi [10], yeni üretim tesislerinin seçimi [11], tarımsal ürün depolarının seçimi [12], temizleme sistemlerinin seçimi ve değerlendirilmesi alanlarıdır [13]. AHP ayrıca, eğitim, mühendislik, endüstri, yönetim, politik, sosyal ve spor alanlarında da uygulanmıştır [7]

Bu çalışmada, kişi takip cihazı üreten 5 farklı firmaya ait 5 farklı ürün kişi takip cihazlarının piyasa özellikleri dikkate alınarak belirlenen on adet kriter kapsamında değerlendirilmiştir. Çalışmada sektörle ilgili alanında uzman üç karar vericiye anket soruları uygulanarak ikili karşılaştırma matrislerinden objektif değerler elde edilmeye çalışılmıştır. Belirlenen kriterler ve karar vericilerin değerlendirmeleri kapsamında firmaların ürettiği kişi takip cihazlarına analitik hiyerarşi süreci uygulanmış ve hangi firmanın ürettiği kişi takip cihazının kullanıcı tarafindan satın alınmasının daha uygun olabileceği tespit edilmeye çalışılmıştır. Çalışmaya dâhil edilen firma isimlerinin gizlilik esası ilkeleri gereği açıklanmaması uygun görülmüştür.

\section{KISŞI TAKİP CIHAZI (PERSON TRACKING DEVICE)}

Kişi Takip Cihazları genel olarak, GSM üzerinden konumlama yapıp bu konum bilgisini GPRS üzerinden hizmet sağlayıcılar (server) aracılığı ile kullanıcıya ileten yani uydulardan konum tespiti yapan ve cihaz içerisindeki sim kartlar aracılığ 1 ile konumunu kullanıcıya bildiren sistemlerdir. Kişi takip cihazı ile internete bağlı herhangi bir bilgi akışını sağlayan telekomünikasyon iletişim aracından (bilgisayar, tablet veya cep telefonu) kullanıcıya bildirilen internet adresi girilerek harita üzerinden kişi takip cihazınızın gönderdiği konum çevrimiçi olarak anında görülebilmektedir.

Kişi takip cihazlarında konum gönderme sıklığ1 kullanıcı ihtiyacına göre değiştirilebilen bir ayarlamadır. Kullanıcı bu ayarı değiştirerek batarya kullanım süresini uzatabilmektedir. Örneğin, dakikada bir konum verisini görmek isteyen bir kullanıcının cihazının açık kalma süresi ortalama olarak 8 Saat'tir. Onbeş (15) dakikada bir konum verisini görmek isteyen bir kullanıcının cihazının açık kalma süresi ise yaklaşık 30 Saat'tir. 
Kişi takip cihazlarında cihazlarda acil durum butonu (SOS) bulunmaktadir. Bu buton acil bir durumla karşılaşıldığında kullanıcı tarafindan aktif hale getirilerek harita üzerinde cihazın uyarı sinyali vermesini sağlamaktadır. Verilen bu uyarı sinyali kullanıcının konumu hakkından bilgi edinmek isteyen kişilere SMS, e-posta veya otomatik arama şeklinde iletilmektedir. Bu uyarı sinyali sayesinde kullanıcının karş1laşabileceği herhangi bir olağandış1 durumda kullanıcıyla iletişim halinde olan kişilere bilgi sağlanmaktadır.

Kişi takip cihazı açık olduğu sürece konum bilgisi harita üzerinden takip edilebilmektedir. Cihazla ilgili olarak beklenmeyen bir durum olursa, cihazın kapanması veya şarjının bitmesi gibi durumlarda son konum verisine bakılarak kullanıcının konumu yaklaşık olarak tahmin edilebilir. Böylelikle cihazı herhangi bir nedenden ötürü kapalı olan kullanıcıya acil bir durumda ulaşılması mümkün olmaktadır.

Bazı kişi takip cihazlarında uzaktan komut gönderilerek cihaz ayarlarını değiştirebilme özelliği bulunmaktadır. Herhangi bir telefondan kısa mesaj gönderilerek cihazların ayarlarını değiştirmek mümkündür. Örneğin, kişi takip cihazı kullanıcıya teslim edildikten sonra batarya kullanım süresinin uzatılabilmesi için konum gönderme sıklığının değiştirilmesi istenebilir. $\mathrm{Bu}$ gibi durumlarda özel olarak yazılmış kodlarla herhangi bir telefondan kişi takip cihazına gönderilen kısa mesaj vasıtasıyla konum gönderme sıklığı değiştirilerek batarya kullanım süresini uzatmak mümkün olabilmektedir. Cihaz ayarlarının uzaktan komut göndermek yoluyla değiştirilebilmesinin hem zaman hem de maliyet açısından kullanıcıya önemli avantajlar sağladığ söylenebilir.

\section{ANALITIK HIYYERARŞI SÜRECININ UYGULAMASI (APPLICATION OF THE ANALYTIC HIERARCHY PROCESS) 3.1. Karar Verme Problemi Tanımlanmasl ve Yapisal Hiyerarşinin Oluşturulması (Decision Making Problem Identification and Establishment of the Structural Hierarchy)}

$\mathrm{Bu}$ uygulamada, kişi takip cihazlarında bulunması gereken önemli özelikler (kriterlerin) ile mevcut piyasada kişi takip cihazı üretimi yapan firmaların ürettiği ürünler (alternatiflerin) arasında AHP süreci uygulanarak, hangi firmanın ürettiği ürünün kullanıcı seçimi açısından daha faydalı olabileceği ortaya konmaya çalışılmıştır. Kişi takip cihazı üreten 5 farklı firma 5 farklı ürün piyasa özellikleri ve uzman görüşleri dikkate alınarak belirlenen on adet kriter kapsamında değerlendirilmiştir. Kriterler belirlenirken fiyat kriteri değerlendirme sürecinde karar vericilerle birlikte ele alınarak bu çalışmanın uygulama yapıldığı alanda tüketiciler açısından çok önemli görülmediği için sürece dahil edilmemiştir.

Kişi Takip Cihazlarını değerlendirmek için belirlenen 10 kriter ve 5 alternatif aşağıda belirtildiği gibidir.

\section{Kriterler (Criteria):}

1. CA: Cihaz Ağırlığı (gr)

2. ÇYTG: Çift Yönlü Telefon Görüşmesi

3. TNK: Telefon Numarası Kaydedebilme

4. OD: Ortam Dinleme

5. LCD: LCD Ekran

6. ŞOS: Şarj Olma Süresi (saat)

7. KS: Kullanım Süresi (15dak bir veri gönderme)

8. Hí: Haritadan İzleyebilme

9. UCAD: Uzaktan cihaz ayarlarını değiştirebilme

10. GPS: GPS Alıcı Kanal Sayısı

Alternatifler (Alternatives):

Şuan piyasada bulunan 5 adet Kişi Takip Cihazı markası belirlenmiştir. $\mathrm{Bu}$ markalar yani Alternatiflerimiz;
a) Marka-1 $\quad \rightarrow$ Ürün-1
b) Marka-2 $\rightarrow$ Ürün-2
c) Marka-3 $\rightarrow$ Ürün-3
d) Marka-4 $\rightarrow$ Ürün-4
e) Marka-5 $\rightarrow$ Ürün-5

Buna göre problemin yapısal hiyerarşisi Şekil 1'de gösterildiği gibi oluşturulur. 


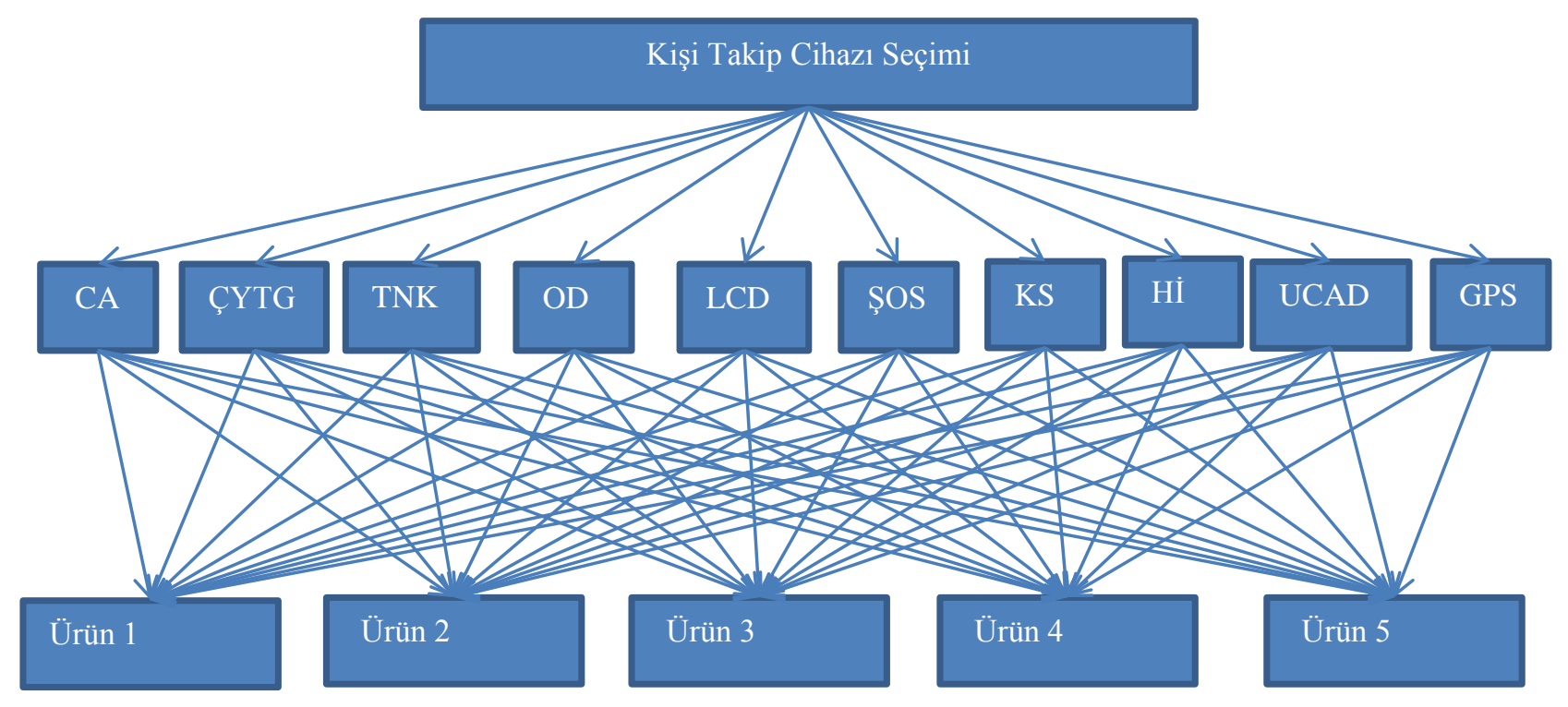

Şekil 1. Kişi takip cihazı seçiminin yapısal hiyerarşisi (Structural hierarchy of the person tracking device selection)

3.2. Kriterlerin ve Alternatiflerin Yüzde Önem Dă̆llımları Belirlenir (Determination of criteria and Percent Importance Distribution of Alternatives)

Kriterlerin ve alternatiflerin karşılaştırma matrisleri oluşturulduktan sonra hem kriterler için hem de alternatifler için ayrı ayrı yüzde önem dağılımları bulunur. Bunun için karşılaştırma matrisini oluşturan sütun vektörlerinden yararlanılır ve $n$ adet $n$ bileşenli sütun vektörü oluşturulur.

\subsection{Kriterlerin yüzde önem dă̆llımlarının belirlenmesi (Determination of criteria importance percent distribution)}

$\mathrm{Bu}$ kısımda sadece kriterler için yüzde önem dağılımları hesaplanmaktadır. Öncelikle kriterlerin ikili karşılaştırma matrisleri hazırlanıp sonrasında kriterlerin normalizasyonları hesaplanarak kriterlerin öncelik değerleri belirlenir.

\subsubsection{Kriterlerin ikili karşılaştırma matrisleri (Pairwise comparison matrix of criteria)}

Kişi Takip Cihazının seçimi için 10 adet kriter belirlenmiştir. Belirlenen kriterlerin ikili karşılaştırma matrisi " $C$ " aşağıdaki gibidir.

Tablo 3.1 Kriterlerin ikili karşılaştırılma matrisi (Pairwise comparison matrix of criteria)

\begin{tabular}{|c|l|l|l|l|}
\hline \multicolumn{5}{|c|}{ Kriterler } \\
\hline \multicolumn{4}{|c|}{ Karşılaştırma matrisi } \\
\hline & $C_{1}$ & $C_{2}$ & $\ldots$ & $C_{m}$ \\
\hline$C_{1}$ & $C_{11}$ & $C_{12}$ & $\ldots$ & $C_{1 m}$ \\
\hline$C_{2}$ & $C_{21}$ & $C_{22}$ & $\ldots$ & $C_{2 m}$ \\
\hline$\ldots$ & $\ldots$ & $\ldots$ & $\ldots$ & $\ldots$ \\
\hline$C_{m}$ & $C_{m 1}$ & $C_{m 2}$ & $\ldots$ & $C_{m m}$ \\
\hline
\end{tabular}

Buna göre; Karşılaştırma matrisindeki değerler karar vericilere bağlı olarak değişiklik gösterebilir. Burada önemli olan husus çalışmaya katılan karar vericilerin değerlendirmelidir.

Tablo 3.2. Karşılaștırma matrisi

(Comparison matrix)

\begin{tabular}{|c|c|c|c|c|c|c|c|c|c|c|}
\hline \multicolumn{10}{|c|}{$\begin{array}{l}\text { ison matrix) } \\
\text { Kriterler }\end{array}$} & \\
\hline \multicolumn{11}{|c|}{ Karşılaștırma Matrisi } \\
\hline & 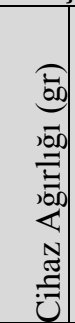 & 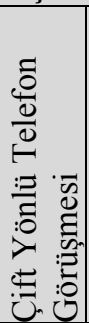 & 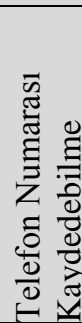 & 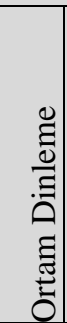 & 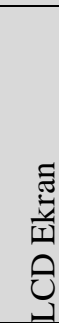 & 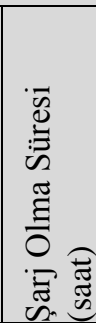 & 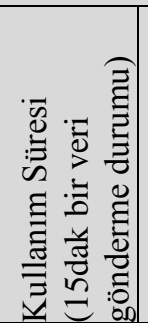 & 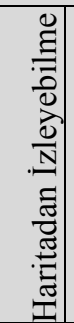 & 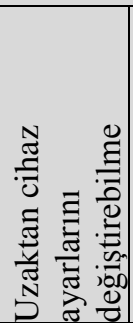 & 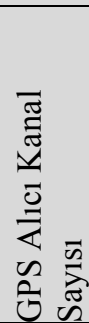 \\
\hline Cihaz Ağırlığı (gr) & 1 & 1 & 3 & 1 & 1 & 5 & $1 / 3$ & $1 / 3$ & 7 & 1 \\
\hline Çift Yönlü Telefon Görüşmesi & 1 & 1 & 3 & 1 & 1 & 5 & $1 / 3$ & $1 / 3$ & 7 & 1 \\
\hline
\end{tabular}




\begin{tabular}{|l|c|c|c|c|c|c|c|c|c|c|} 
Telefon Numarası Kaydedebilme & $1 / 3$ & $1 / 3$ & 1 & $1 / 3$ & $1 / 3$ & 3 & $1 / 5$ & $1 / 5$ & 5 & $1 / 3$ \\
\hline Ortam Dinleme & 1 & 1 & 3 & 1 & 1 & 5 & $1 / 3$ & $1 / 3$ & 7 & 1 \\
\hline LCD Ekran & 1 & 1 & 3 & 1 & 1 & 5 & $1 / 3$ & $1 / 3$ & 7 & 1 \\
\hline Şarj Olma Süresi (saat) & $1 / 5$ & $1 / 5$ & $1 / 3$ & $1 / 5$ & $1 / 5$ & 1 & $1 / 7$ & $1 / 7$ & 3 & $1 / 5$ \\
\hline Kullanım Süresi (15dak bir veri gönderme) & 3 & 3 & 5 & 3 & 3 & 7 & 1 & 1 & 9 & 3 \\
\hline Haritadan İzleyebilme & 3 & 3 & 5 & 3 & 3 & 7 & 1 & 1 & 9 & 3 \\
\hline Uzaktan cihaz ayarlarını değiştirebilme & $1 / 7$ & $1 / 7$ & $1 / 5$ & $1 / 7$ & $1 / 7$ & $1 / 3$ & $1 / 9$ & $1 / 9$ & 1 & $1 / 7$ \\
\hline GPS Alıcı Kanal Sayısı & 1 & 1 & 3 & 1 & 1 & 5 & $1 / 3$ & $1 / 3$ & 7 & 1 \\
\hline
\end{tabular}

Kriterlerin normalizasyonlarının hesaplanmasl (The calculation of the normalization criteria)

Tablo 3.3. Kriterler için normalizasyon matrisi (Normalization matrix for criteria)

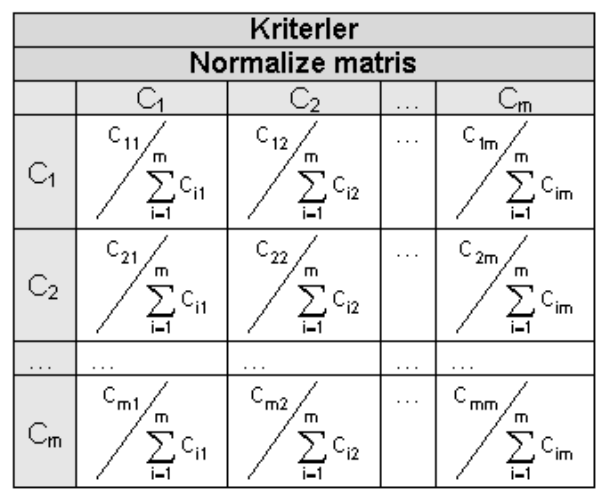

Buna göre; Belirlenen Kriterlerin Normalizasyon Matrisi “CN” aşağıdaki gibi oluşmaktadır.

Tablo 3.4. Normalizsyon matris

(Normalization matrix)

\begin{tabular}{|c|c|c|c|c|c|c|c|c|c|c|}
\hline \multicolumn{11}{|c|}{11} \\
\hline \multicolumn{11}{|c|}{ Normalize Matris } \\
\hline & 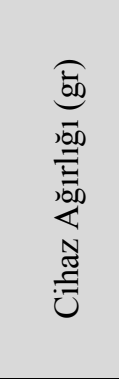 & 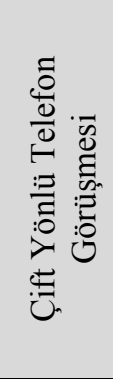 & 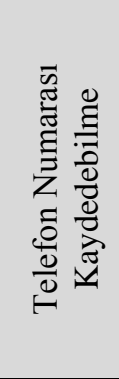 & 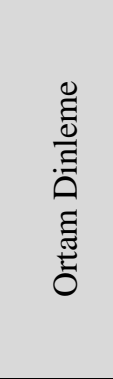 & 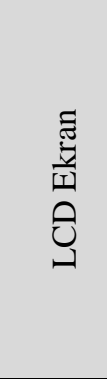 & 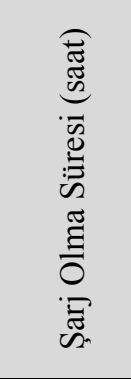 & 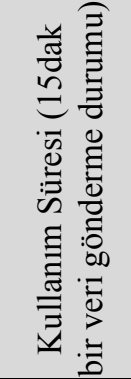 & 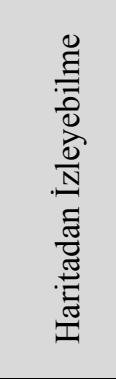 & 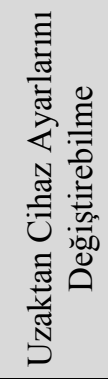 & 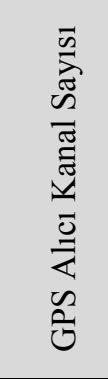 \\
\hline Cihaz Ağırlığı (gr) & \begin{tabular}{|l|}
0,0856 \\
44372
\end{tabular} & $\begin{array}{l}0,0856 \\
44372\end{array}$ & $\begin{array}{c}0,1130 \\
65327\end{array}$ & $\begin{array}{c}0,0856 \\
4437\end{array}$ & $\begin{array}{c}0,0856 \\
4437\end{array}$ & $\begin{array}{c}0,11538 \\
4615\end{array}$ & $\begin{array}{c}0,08089 \\
3683\end{array}$ & $\begin{array}{c}0,0808 \\
9368\end{array}$ & $\begin{array}{c}0,1129 \\
0323\end{array}$ & $\begin{array}{c}0,0856 \\
4437\end{array}$ \\
\hline $\begin{array}{c}\text { Çift Yönlü Telefon } \\
\text { Görüşmesi }\end{array}$ & $\begin{array}{c}0,0856 \\
44372\end{array}$ & $\begin{array}{l}0,0856 \\
44372\end{array}$ & $\begin{array}{c}0,1130 \\
65327\end{array}$ & $\begin{array}{c}0,0856 \\
4437\end{array}$ & $\begin{array}{c}0,0856 \\
4437\end{array}$ & $\begin{array}{c}0,11538 \\
4615\end{array}$ & $\begin{array}{c}0,08089 \\
3683\end{array}$ & $\begin{array}{c}0,0808 \\
9368\end{array}$ & $\begin{array}{c}0,1129 \\
0323\end{array}$ & $\begin{array}{c}0,0856 \\
4437\end{array}$ \\
\hline $\begin{array}{l}\text { Telefon Numaras1 } \\
\text { Kaydedebilme }\end{array}$ & $\begin{array}{l}0,0285 \\
48124\end{array}$ & $\begin{array}{l}0,0285 \\
48124\end{array}$ & $\begin{array}{l}0,0376 \\
88442\end{array}$ & $\begin{array}{c}0,0285 \\
4812\end{array}$ & $\begin{array}{c}0,0285 \\
4812\end{array}$ & $\begin{array}{c}0,06923 \\
0769\end{array}$ & $\begin{array}{c}0,04853 \\
621\end{array}$ & $\begin{array}{c}0,0485 \\
3621\end{array}$ & $\begin{array}{c}0,0806 \\
4516\end{array}$ & $\begin{array}{c}0,0285 \\
4812\end{array}$ \\
\hline Ortam Dinleme & $\begin{array}{c}0,0856 \\
44372 \\
\end{array}$ & $\begin{array}{l}0,0856 \\
44372\end{array}$ & $\begin{array}{c}0,1130 \\
65327\end{array}$ & $\begin{array}{c}0,0856 \\
4437\end{array}$ & $\begin{array}{c}0,0856 \\
4437\end{array}$ & $\begin{array}{c}0,11538 \\
4615\end{array}$ & $\begin{array}{c}0,08089 \\
3683\end{array}$ & $\begin{array}{c}0,0808 \\
9368\end{array}$ & $\begin{array}{c}0,1129 \\
0323\end{array}$ & $\begin{array}{c}0,0856 \\
4437\end{array}$ \\
\hline LCD Ekran & $\begin{array}{l}0,0856 \\
44372\end{array}$ & $\begin{array}{l}0,0856 \\
44372\end{array}$ & $\begin{array}{c}0,1130 \\
65327\end{array}$ & $\begin{array}{c}0,0856 \\
4437\end{array}$ & $\begin{array}{c}0,0856 \\
4437\end{array}$ & $\begin{array}{c}0,11538 \\
4615\end{array}$ & $\begin{array}{c}0,08089 \\
3683\end{array}$ & $\begin{array}{c}0,0808 \\
9368\end{array}$ & $\begin{array}{c}0,1129 \\
0323\end{array}$ & $\begin{array}{c}0,0856 \\
4437\end{array}$ \\
\hline Şarj Olma Süresi (saat) & \begin{tabular}{|l|}
0,0171 \\
28874 \\
\end{tabular} & $\begin{array}{l}0,0171 \\
28874\end{array}$ & $\begin{array}{c}0,0125 \\
62814\end{array}$ & $\begin{array}{c}0,0171 \\
2887\end{array}$ & $\begin{array}{c}0,0171 \\
2887\end{array}$ & $\begin{array}{c}0,02307 \\
6923\end{array}$ & $\begin{array}{c}0,03466 \\
8721\end{array}$ & $\begin{array}{c}0,0346 \\
6872\end{array}$ & $\begin{array}{c}0,0483 \\
871\end{array}$ & $\begin{array}{c}0,0171 \\
2887\end{array}$ \\
\hline
\end{tabular}




\begin{tabular}{|c|c|c|c|c|c|c|c|c|c|c|}
$\begin{array}{c}\text { Kullanım Süresi (15dak bir } \\
\text { veri gönderme) }\end{array}$ & 0,2569 & 0,2569 & 0,1884 & 0,2569 & 0,2569 & 0,16153 & 0,24268 & 0,2426 & 0,1451 & 0,2569 \\
83116 & 33116 & 42211 & 3312 & 3312 & 8462 & 1048 & 8105 & 6129 & 3312 \\
\hline Haritadan İzleyebilme & 0,2569 & 0,2569 & 0,1884 & 0,2569 & 0,2569 & 0,16153 & 0,24268 & 0,2426 & 0,1451 & 0,2569 \\
& 33116 & 33116 & 42211 & 3312 & 3312 & 8462 & 1048 & 8105 & 6129 & 3312 \\
\hline $\begin{array}{c}\text { Uzaktan cihaz ayarlarını } \\
\text { değiştirebilme }\end{array}$ & 0,0122 & 0,0122 & 0,0075 & 0,0122 & 0,0122 & 0,00769 & 0,02696 & 0,0269 & 0,0161 & 0,0122 \\
2491 & 3491 & 37688 & 3491 & 3491 & 2308 & 4561 & 6456 & 2903 & 3491 \\
\hline GPS Alıcı Kanal Sayısı & 0,0856 & 0,0856 & 0,1130 & 0,0856 & 0,0856 & 0,11538 & 0,08089 & 0,0808 & 0,1129 & 0,0856 \\
& 44372 & 44372 & 65327 & 4437 & 4437 & 4615 & 3683 & 9368 & 0323 & 4437 \\
\hline TOPLAM & 1 & 1 & 1 & 1 & 1 & 1 & 1 & 1 & 1 & 1 \\
\hline
\end{tabular}

\subsubsection{Kriterlerin önceliklerinin hesaplanmast (Calculation of the Priorities of the Criteria)}

Tablo 3.5. Kriterler için öncelik değerler matrisi (Priority value matrix for criteria)

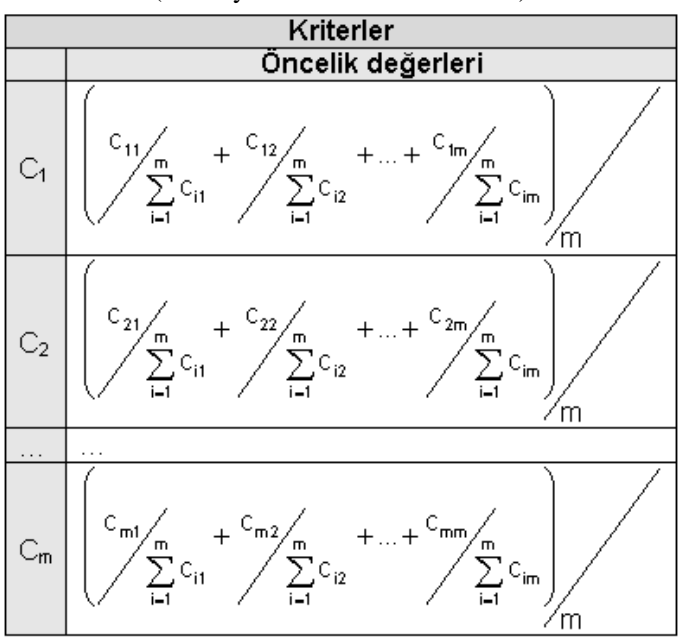

Buna göre; Kriterlerin Öncelik Değerler Matrisi “ $C W$ " aşağıdaki gibi oluşmaktadır.

Tablo 3.6. Öncelik değerler matrisi (Priority value matrix)

\begin{tabular}{|c|c|}
\hline \multicolumn{2}{|c|}{ CW --- Kriterler } \\
\hline & Öncelik Değerleri \\
\hline Cihaz Ağırlığı (gr) & 0,093136239 \\
\hline Çift Yönlü Telefon Görüşmesi & 0,093136239 \\
\hline Telefon Numarası Kaydedebilme & 0,042737741 \\
\hline Ortam Dinleme & 0,093136239 \\
\hline LCD Ekran & 0,093136239 \\
\hline Şarj Olma Süresi (saat) & 0,023900865 \\
\hline Kullanım Süresi (15dak bir) & 0,226516964 \\
\hline Haritadan İzleyebilme & 0,226516964 \\
\hline $\begin{array}{c}\text { Uzaktan cihaz ayarlarını } \\
\text { değiştirebilme }\end{array}$ & 0,01464627 \\
\hline GPS Alıcı Kanal Sayısı & 0,093136239 \\
\hline TOPLAM & 1 \\
\hline
\end{tabular}

Alternatiflerin yüzde önem dağllımlarının belirlenmesi (Determination of importance percentage distribution of alternatives)

$\mathrm{Bu}$ kısımda sadece kriterler için yüzde önem dağılımları hesaplanmaktadır. Öncelikle kriterlerin ikili karşılaştırma matrisleri hazırlanıp sonrasında kriterlerin normalizasyonları hesaplanarak kriterlerin öncelik değerleri belirlenmektedir.

\subsubsection{Alternatiflerin ikili karşılaştırma matrisleri (Pairwise comparison matrix of alternatives)}

Kişi Takip Cihazının seçimi için 5 alternatif belirlenmiştir. Belirlenen alternatiflerin ikili karşılaştırma matrisleri "Ax" aşağıdaki gibidir. . Madde 3.2.1.1. deki (Tablo 3.1 Kriterlerin ikili karşılaştırılma matrisi) dikkate alındığında;

Tablo 3.7. Cihaz ağırlığına göre karşılaştırma matrisi (Comparison matrix by weight of the device)

\begin{tabular}{|c|c|c|c|c|c|}
\hline \multicolumn{7}{|c|}{ Ax --- Alternatifler } \\
\hline \multicolumn{7}{|c|}{ Carşızaştırma Matrisi } \\
\hline & Ürün1 & Ürün2 & Ürün3 & Ürün4 & Ürün5 \\
\hline Ürün-1 & 1 & $1 / 5$ & $1 / 7$ & $1 / 3$ & $1 / 3$ \\
\hline Ürün-2 & 5 & 1 & $1 / 3$ & 3 & 3 \\
\hline Ürün-3 & 7 & 3 & 1 & 5 & 5 \\
\hline Ürün-4 & 3 & $1 / 3$ & $1 / 5$ & 1 & 1 \\
\hline Ürün-5 & 3 & $1 / 3$ & $1 / 5$ & 1 & 1 \\
\hline
\end{tabular}

Tablo 3.8. Çift yönlü telefon görüşmesine göre karşılaştırılma matrisi

(Comparison matrix according to the two-way telephone conversation)

\begin{tabular}{|c|c|c|c|c|c|}
\hline \multicolumn{6}{|c|}{ Ax --- Alternatifler } \\
\hline \multicolumn{6}{|c|}{ Karşılaştırma Matrisi } \\
\hline \multicolumn{3}{|c|}{ Çift Yönlü Telefon Görüşmesine Göre } \\
\hline & Ürün1 & Ürün2 & Ürün3 & Ürün4 & Ürün5 \\
\hline Ürün-1 & 1 & 1 & 7 & 7 & 7 \\
\hline Ürün-2 & 1 & 1 & 7 & 7 & 7 \\
\hline Ürün-3 & $1 / 7$ & $1 / 7$ & 1 & 1 & 1 \\
\hline Ürün-4 & $1 / 7$ & $1 / 7$ & 1 & 1 & 1 \\
\hline Ürün-5 & $1 / 7$ & $1 / 7$ & 1 & 1 & 1 \\
\hline
\end{tabular}


Tablo 3.9. Telefon numarası kaydedebilme sayısına göre karşılaştırma matrisi

(Comparison matrix by the number of telephone number recording ability)

\begin{tabular}{|c|c|c|c|c|c|}
\hline \multicolumn{6}{|c|}{ Karşıllaştırma Matrisi } \\
\hline & Ürün1 & Ürün2 & Ürün3 & Ürün4 & Ürün5 \\
\hline Telefon Numarası Kaydedebilme Sayısına Göre \\
\hline Ürün-1 & 1 & 5 & 1 & 5 & 1 \\
\hline Ürün-2 & $1 / 5$ & 1 & $1 / 5$ & 1 & $1 / 5$ \\
\hline Ürün-3 & 1 & 5 & 1 & 5 & 1 \\
\hline Ürün-4 & $1 / 5$ & 1 & $1 / 5$ & 1 & $1 / 5$ \\
\hline Ürün-5 & 1 & 5 & 1 & 5 & 1 \\
\hline
\end{tabular}

Tablo 3.10. Ortam dinleme özelliğine göre karşılaştırılma matrisi

(Comparison matrix according to environment listening feature)

Ax --- Alternatifler

\begin{tabular}{|c|c|c|c|c|c|}
\hline \multicolumn{7}{|c|}{ Ax --- Alternatifler } \\
\hline \multicolumn{7}{|c|}{ Ortam Dinleme Özelliğine Göre } \\
\hline & Ürün1 & Ürün2 & Ürün3 & Ürün4 & Ürün5 \\
\hline Ürün-1 & 1 & 7 & 7 & 7 & 1 \\
\hline Ürün-2 & $1 / 7$ & 1 & 1 & 1 & $1 / 7$ \\
\hline Ürün-3 & $1 / 7$ & 1 & 1 & 1 & $1 / 7$ \\
\hline Ürün-4 & $1 / 7$ & 1 & 1 & 1 & $1 / 7$ \\
\hline Ürün-5 & 1 & 7 & 7 & 7 & 1 \\
\hline
\end{tabular}

Tablo 3.11. LCD ekran özelliğine göre karşılaştırılma matrisi

(Comparison matrix according to the LCD screen feature)

\begin{tabular}{|c|c|c|c|c|c|}
\hline \multicolumn{6}{|c|}{ Ax --- Alternatifler } \\
\hline \multicolumn{6}{|c|}{ Karşılaştırma Matrisi } \\
\hline & Ürün1 & Ürün2 & Ürün3 & Ürün4 & Ürün5 \\
\hline Ürün-1 & 1 & 7 & 7 & 7 & 7 \\
\hline Ürün-2 & $1 / 7$ & 1 & 1 & 1 & 1 \\
\hline Ürün-3 & $1 / 7$ & 1 & 1 & 1 & 1 \\
\hline Ürün-4 & $1 / 7$ & 1 & 1 & 1 & 1 \\
\hline Ürün-5 & $1 / 7$ & 1 & 1 & 1 & 1 \\
\hline
\end{tabular}

Tablo 3.12. Şarj olma süresine göre karşılaştırma matrisi

(Comparison matrix according to the charging time)

\begin{tabular}{|l|c|c|c|c|c|}
\hline \multicolumn{7}{|c|}{ Ax --- Alternatifler } \\
\hline \multicolumn{6}{|c|}{ Karşırjaştırma Matrisi } \\
\hline & Ürün1 & Ürün2 & Ürün3 & Ürün4 & Ürün5 \\
\hline Ürün-1 & 1 & 1 & $1 / 5$ & $1 / 3$ & 1 \\
\hline Ürün-2 & 1 & 1 & $1 / 5$ & $1 / 3$ & 1 \\
\hline Ürün-3 & 5 & 5 & 1 & 3 & 5 \\
\hline Ürün-4 & 3 & 3 & $1 / 3$ & 1 & 3 \\
\hline Ürün-5 & 1 & 1 & $1 / 5$ & $1 / 3$ & 1 \\
\hline
\end{tabular}

Tablo 3.13. Kullanım süresine (15dak bir veri gönderme) göre karşılaştırma matrisi

(Comparison matrix by lifetime (15min sending data))

\begin{tabular}{|c|c|c|c|c|c|}
\hline \multicolumn{5}{|c|}{ Ax --- Alternatifler } \\
\hline \multicolumn{5}{|c|}{ Karşılaştırma Matrisi } \\
\hline \multicolumn{6}{|c|}{ Kullanım Süresine (15dak bir veri gönderme) } \\
\hline & Ürün1 & Ürün2 & Ürün3 & Ürün4 & Ürün5 \\
\hline Ürün-1 & 1 & 9 & 3 & 5 & 7 \\
\hline Ürün-2 & $1 / 9$ & 1 & $1 / 7$ & $1 / 5$ & $1 / 3$ \\
\hline Ürün-3 & $1 / 3$ & 7 & 1 & 3 & 5 \\
\hline Ürün-4 & $1 / 5$ & 5 & $1 / 3$ & 1 & 3 \\
\hline Ürün-5 & $1 / 7$ & 3 & $1 / 5$ & $1 / 3$ & 1 \\
\hline
\end{tabular}

Tablo 3.14. Haritadan izleyebilme özelliğine göre karşılaştırılma matrisi

(Comparison matrix according to tracking on the map feature)

\begin{tabular}{|c|c|c|c|c|c|}
\hline \multicolumn{6}{|c|}{ Kx --- Alternatifler } \\
\hline \multicolumn{6}{|c|}{ Harşlaştırma Matrisi } \\
\hline & Ürün1 & Ürün2 & Ürün3 & Ürün4 & Ürün5 \\
\hline Ürün-1 & 1 & 1 & 1 & 1 & 1 \\
\hline Ürün-2 & 1 & 1 & 1 & 1 & 1 \\
\hline Ürün-3 & 1 & 1 & 1 & 1 & 1 \\
\hline Ürün-4 & 1 & 1 & 1 & 1 & 1 \\
\hline Ürün-5 & 1 & 1 & 1 & 1 & 1 \\
\hline
\end{tabular}

Tablo 3.15. Uzaktan cihaz ayarlarını değiştirebilme özelliğine göre karşılaştırılma matrisi

(Comparison matrix according to remote changing of device settings feature)

\begin{tabular}{|c|c|c|c|c|c|}
\hline \multicolumn{6}{|c|}{ Ax --- Alternatifler } \\
\hline \multicolumn{6}{|c|}{ Uarşılaştırma Matrisi } \\
\hline Uzaktan Cihaz Ayarlarını Değiştirebilme \\
\hline Ürün-1 & 1 & 1 & 1 & 1 & 1 \\
\hline Ürün-2 & 1 & 1 & 1 & 1 & 1 \\
\hline Ürün-3 & 1 & 1 & 1 & 1 & 1 \\
\hline Ürün-4 & 1 & 1 & 1 & 1 & 1 \\
\hline Ürün-5 & 1 & 1 & 1 & 1 & 1 \\
\hline
\end{tabular}

Tablo 3.16. GPS alıcı kanal sayısına göre (By the number of GPS receiver channels)

\begin{tabular}{|l|c|c|c|c|c|}
\hline \multicolumn{7}{|c|}{ Ax --- Alternatifler } \\
\hline \multicolumn{7}{|c|}{ GPS Alıc Kanal Sayısına Göre } \\
\hline & Ürün1 & Ürün2 & Ürün3 & Ürün4 & Ürün5 \\
\hline Ürün-1 & 1 & 5 & 9 & 3 & 3 \\
\hline Ürün-2 & $1 / 5$ & 1 & 7 & 3 & 3 \\
\hline Ürün-3 & $1 / 9$ & $1 / 7$ & 1 & $1 / 7$ & $1 / 7$ \\
\hline Ürün-4 & $1 / 3$ & $1 / 3$ & 7 & 1 & 1 \\
\hline Ürün-5 & $1 / 3$ & $1 / 3$ & 7 & 1 & 1 \\
\hline
\end{tabular}


İkili karşılaştırma matrisleri geliştirildikten sonra, karşılaştırılan her elemanın önceliğinin hesaplanmasına geçilmektedir. Öncelik değerlerinin hesaplanması kriterlerin normalize edilmesini içermektedir. Bu amaçla kullanılan çeşitli yöntemler mevcuttur. Ancak literatürde en yaygın olarak kullanılan normalizasyon yönteminde her sütunun elemanları o sütunun toplamına bölünmektedir. Elde edilen değerlerin satır toplamı alınıp, bu toplam satırdaki eleman sayısına bölünmektedir [14].

\subsubsection{Alternatiflerin normalizasyonlarının hesaplanmasl (Calculation of normalization of alternatives)}

Belirlediğimiz Alternatiflerin Normalizasyon Matrisleri "ANx" aşağıdaki gibi oluşmaktadır. Madde 3.2.1.2. deki (Tablo 3.1 Kriterlerin ikili karşılaştırılma matrisi) dikkate alındığında;

Çizelge 3.17. Cihaz ağırlığına göre normalizasyon matrisi

(Normalization matrix according to the device weight)

\begin{tabular}{|c|c|c|c|c|c|}
\hline \multicolumn{7}{|c|}{ ANx --- Alternatifler } \\
\hline \multicolumn{6}{|c|}{ Ciharmalize Matris } \\
\hline & Ürün1 1 & Ürün2 & Ürün3 & Ürün4 & Ürün5 \\
\hline & 0,0526 & 0,0410 & 0,0761 & 0,0322 & 0,0322 \\
Ürün-1 & 31579 & 9589 & 42132 & 58065 & 58065 \\
\hline & 0,2631 & 0,2054 & 0,1776 & 0,2903 & 0,2903 \\
Ürün-2 & 57895 & 79452 & 64975 & 22581 & 22581 \\
\hline & 0,3684 & 0,6164 & 0,5329 & 0,4838 & 0,4838 \\
Ürün-3 & 21053 & 38356 & 94924 & 70968 & 70968 \\
\hline & 0,1578 & 0,0684 & 0,1065 & 0,0967 & 0,0967 \\
Ürün-4 & 94737 & 93151 & 98985 & 74194 & 74194 \\
\hline & 0,1578 & 0,0684 & 0,1065 & 0,0967 & 0,0967 \\
Ürün-5 & 94737 & 93151 & 98985 & 74194 & 74194 \\
\hline Toplam & 1 & 1 & 1 & 1 & 1 \\
\hline
\end{tabular}

Tablo 3.18. Çift yönlü telefon görüşmesine göre (According to the two-way telephone conversation)

\begin{tabular}{|c|c|c|c|c|c|}
\hline \multicolumn{6}{|c|}{ ANx --- Alternatifler } \\
\hline \multicolumn{7}{|c|}{ Çift Yönlü Telefon Görüşmesine Göre } \\
\hline & Ürün1 & Ürün2 & Ürün3 & Ürün4 & Ürün5 \\
\hline & 0,4117 & 0,4117 & 0,4117 & 0,4117 & 0,4117 \\
Ürün-1 & 64706 & 64706 & 64706 & 64706 & 64706 \\
\hline \multirow{3}{*}{} & 0,4117 & 0,4117 & 0,4117 & 0,4117 & 0,4117 \\
Ürün-2 & 64706 & 64706 & 64706 & 64706 & 64706 \\
\hline \multirow{3}{*}{} & 0,0588 & 0,0588 & 0,0588 & 0,0588 & 0,0588 \\
Ürün-3 & 23529 & 23529 & 23529 & 23529 & 23529 \\
\hline \multirow{3}{*}{} & 0,0588 & 0,0588 & 0,0588 & 0,0588 & 0,0588 \\
Ürün-4 & 23529 & 23529 & 23529 & 23529 & 23529 \\
\hline \multirow{3}{*}{} & 0,0588 & 0,0588 & 0,0588 & 0,0588 & 0,0588 \\
Ürün-5 & 23529 & 23529 & 23529 & 23529 & 23529 \\
\hline
\end{tabular}

Tablo 3.19. Telefon numarası kaydedebilme sayısına göre normalizasyon matrisi

(Normalization matrix by the number of telephone number recording ability)

\begin{tabular}{|c|c|c|c|c|c|}
\hline \multicolumn{6}{|c|}{ ANx --- Alternatifler } \\
\hline \multicolumn{6}{|c|}{ Normalize Matris } \\
\hline \multicolumn{6}{|c|}{ Telefon Numarası Kaydedebilme Sayısına Göre } \\
\hline & Ürün1 & Ürün2 & Ürün3 & Ürün4 & Ürün5 \\
\hline & 0,2941 & 0,2941 & 0,2941 & 0,2941 & 0,2941 \\
Ürün-1 & 17647 & 17647 & 17647 & 17647 & 17647 \\
\hline & 0,0588 & 0,0588 & 0,0588 & 0,0588 & 0,0588 \\
Ürün-2 & 23529 & 23529 & 23529 & 23529 & 23529 \\
\hline & 0,2941 & 0,2941 & 0,2941 & 0,2941 & 0,2941 \\
Ürün-3 & 17647 & 17647 & 17647 & 17647 & 17647 \\
\hline & 0,0588 & 0,0588 & 0,0588 & 0,0588 & 0,0588 \\
Ürün-4 & 23529 & 23529 & 23529 & 23529 & 23529 \\
\hline & 0,2941 & 0,2941 & 0,2941 & 0,2941 & 0,2941 \\
Ürün-5 & 17647 & 17647 & 17647 & 17647 & 17647 \\
\hline Toplam & 1 & 1 & 1 & 1 & 1 \\
\hline
\end{tabular}

Tablo 3.20. Ortam dinleme özelliğine göre normalizasyon matrisi

(Normalization matrix according to environment listening feature)

\begin{tabular}{|l|c|c|c|c|c|}
\hline \multicolumn{6}{|c|}{ ANx --- Alternatifler } \\
\hline \multicolumn{6}{|c|}{ Normalize Matris } \\
\hline & Ürün1 & Ürün2 & Ürün3 & Ürün4 & Ürün5 \\
\hline & 0,4117 & 0,4117 & 0,4117 & 0,4117 & 0,4117 \\
\hline \multirow{3}{*}{ Ürün-1 } & 64706 & 64706 & 64706 & 64706 & 64706 \\
\hline \multirow{4}{*}{} & 0,0588 & 0,0588 & 0,0588 & 0,0588 & 0,0588 \\
Ürün-2 & 23529 & 23529 & 23529 & 23529 & 23529 \\
\hline \multirow{3}{*}{ Ürün-3 } & 0,0588 & 0,0588 & 0,0588 & 0,0588 & 0,0588 \\
& 23529 & 23529 & 23529 & 23529 & 23529 \\
\hline \multirow{3}{*}{ Ürün-4 } & 0,0588 & 0,0588 & 0,0588 & 0,0588 & 0,0588 \\
& 23529 & 23529 & 23529 & 23529 & 23529 \\
\hline \multirow{3}{*}{ Ürün-5 } & 0,4117 & 0,4117 & 0,4117 & 0,4117 & 0,4117 \\
\hline Toplam & 64706 & 64706 & 64706 & 64706 & 64706 \\
\hline
\end{tabular}

Tablo 3.21. LCD ekran özelliğine göre normalizasyon matrisi

(Normalization matrix according to the LCD screen feature)

\begin{tabular}{|l|c|c|c|c|c|}
\hline \multicolumn{6}{|c|}{ ANx --- Alternatifler } \\
\hline \multicolumn{6}{|c|}{ LCD Ekran Özelliğine Göre } \\
\hline & Ürün1 & Ürün2 & Ürün3 & Ürün4 & Ürün5 \\
\hline & 0,6363 & 0,6363 & 0,6363 & 0,6363 & 0,6363 \\
Ürün-1 & 63636 & 63636 & 63636 & 63636 & 63636 \\
\hline & 0,0909 & 0,0909 & 0,0909 & 0,0909 & 0,0909 \\
Ürün-2 & 09091 & 09091 & 09091 & 09091 & 09091 \\
\hline & 0,0909 & 0,0909 & 0,0909 & 0,0909 & 0,0909 \\
Ürün-3 & 09091 & 09091 & 09091 & 09091 & 09091 \\
\hline & 0,0909 & 0,0909 & 0,0909 & 0,0909 & 0,0909 \\
Ürün-4 & 09091 & 09091 & 09091 & 09091 & 09091 \\
\hline \multirow{3}{*}{} & 0,0909 & 0,0909 & 0,0909 & 0,0909 & 0,0909 \\
Ürün-5 & 09091 & 09091 & 09091 & 09091 & 09091 \\
\hline Toplam & 1 & 1 & 1 & 1 & 1 \\
\hline
\end{tabular}


Tablo 3.22. Şarjolma süresine göre (According to the charging time)

\begin{tabular}{|l|c|c|c|c|c|}
\hline \multicolumn{7}{|c|}{ ANx --- Alternatifler } \\
\hline \multicolumn{7}{|c|}{ Şarj Olma Süresine Göre } \\
\hline & Ürün1 & Ürün2 & Ürün3 & Ürün4 & Ürün5 \\
\hline & 0,0909 & 0,0909 & 0,1034 & 0,0666 & 0,0909 \\
Ürün-1 & 09091 & 09091 & 48276 & 66667 & 09091 \\
\hline & 0,0909 & 0,0909 & 0,1034 & 0,0666 & 0,0909 \\
Ürün-2 & 09091 & 09091 & 48276 & 66667 & 09091 \\
\hline & 0,4545 & 0,4545 & 0,5172 & 0,6 & 0,4545 \\
Ürün-3 & 45455 & 45455 & 41379 & & 45455 \\
\hline & 0,2727 & 0,2727 & 0,1724 & \multirow{2}{*}{0,2} & 0,2727 \\
Ürün-4 & 27273 & 27273 & 13793 & & 27273 \\
\hline \multirow{3}{*}{} & 0,0909 & 0,0909 & 0,1034 & 0,0666 & 0,0909 \\
Ürün-5 & 09091 & 09091 & 48276 & 66667 & 09091 \\
\hline Toplam & 1 & 1 & 1 & 1 & 1 \\
\hline
\end{tabular}

Tablo 3.23. Kullanım süresine göre (According to the lifetime)

\begin{tabular}{|c|c|c|c|c|c|}
\hline & AN & $\mathbf{x} \quad--A^{A}$ & Iternati & ler & \\
\hline Kulla & Iım Süre & sine $(15$ & lak bir & eri gönd & erme) \\
\hline & Ürün1 & Ürün2 & Ürün3 & Ürün4 & Ürün5 \\
\hline & 0,5595 & & 0,6415 & 0,5244 & 0,4285 \\
\hline Ürün-1 & 02664 & 0,36 & 47862 & 75524 & 71429 \\
\hline & 0,0621 & 004 & 0,0305 & 0,0209 & 0,0204 \\
\hline Ürün-2 & 66963 & 0,04 & 49898 & 79021 & 08163 \\
\hline & 0,1865 & & 0,2138 & 0,3146 & 0,3061 \\
\hline Ürün-3 & 00888 & 28 & 49287 & 85315 & 22449 \\
\hline & 0,1119 & 12 & 0,0712 & 0,1048 & 0,1836 \\
\hline Ürün-4 & 00533 & 0,2 & 83096 & 95105 & 73469 \\
\hline & 0,0799 & & 0,0427 & 0,0349 & 0,0612 \\
\hline Ürün-5 & 28952 & 0,12 & 69857 & 65035 & 2449 \\
\hline Toplam & 1 & 1 & 1 & 1 & 1 \\
\hline
\end{tabular}

Tablo 3.24. Haritadan izleyebilme özelliğine göre (According to tracking on the map feature)

\begin{tabular}{|c|c|c|c|c|c|}
\hline \multicolumn{7}{|c|}{ ANx --- Alternatifler } \\
\hline \multicolumn{6}{|c|}{ Normalize Matris } \\
\hline Haritadan İzleyebilme Özelliğine Göre \\
\hline Ürün1 & Ürün2 & Ürün3 & Ürün4 & Ürün5 \\
\hline Ürün-1 & 0,2 & 0,2 & 0,2 & 0,2 & 0,2 \\
\hline Ürün-2 & 0,2 & 0,2 & 0,2 & 0,2 & 0,2 \\
\hline Ürün-3 & 0,2 & 0,2 & 0,2 & 0,2 & 0,2 \\
\hline Ürün-4 & 0,2 & 0,2 & 0,2 & 0,2 & 0,2 \\
\hline Ürün-5 & 0,2 & 0,2 & 0,2 & 0,2 & 0,2 \\
\hline Toplam & 1 & 1 & 1 & 1 & 1 \\
\hline
\end{tabular}

Tablo 3.25. Uzaktan cihaz ayarlarını değiştirebilmesine göre normalizasyon matrisi (Normalization matrix according to remote changing of device settings feature)

\begin{tabular}{|c|c|c|c|c|c|}
\hline \multicolumn{6}{|c|}{ ANx --- Alternatifler } \\
\hline \multicolumn{6}{|c|}{ Normalize Matris } \\
\hline \multicolumn{5}{|c|}{ Uzaktan Cihaz Ayarlarını Değiştirebilme } \\
Özelliğine Göre \\
\hline & Ürün1 & Ürün2 & Ürün3 & Ürün4 & Ürün5 \\
\hline Ürün-1 & 0,2 & 0,2 & 0,2 & 0,2 & 0,2 \\
\hline Ürün-2 & 0,2 & 0,2 & 0,2 & 0,2 & 0,2 \\
\hline Ürün-3 & 0,2 & 0,2 & 0,2 & 0,2 & 0,2 \\
\hline Ürün-4 & 0,2 & 0,2 & 0,2 & 0,2 & 0,2 \\
\hline Ürün-5 & 0,2 & 0,2 & 0,2 & 0,2 & 0,2 \\
\hline
\end{tabular}

Tablo 3.26. GPS alıcı kanal sayısına göre (By the number of GPS receiver channels)

\begin{tabular}{|l|c|c|c|c|c|}
\hline \multicolumn{7}{|c|}{ ANx --- Alternatifler } \\
\hline \multicolumn{7}{|c|}{ Normalize Matris } \\
\hline & Ürün1 & Ürün2 & Ürün3 & Ürürn & Ürün5 \\
\hline & 0,5056 & 0,4098 & 0,3103 & 0,5478 & 0,5478 \\
Ürün-1 & 17978 & 36066 & 44828 & 26087 & 26087 \\
\hline & 0,1011 & 0,0819 & 0,1724 & 0,0608 & 0,0608 \\
Ürün-2 & 23596 & 67213 & 13793 & 69565 & 69565 \\
\hline & 0,0561 & 0,0163 & 0,0344 & 0,0260 & 0,0260 \\
Ürün-3 & 79775 & 93443 & 82759 & 86957 & 86957 \\
\hline & 0,1685 & 0,2459 & 0,2413 & 0,1826 & 0,1826 \\
Ürün-4 & 39326 & 01639 & 7931 & 08696 & 08696 \\
\hline & 0,1685 & 0,2459 & 0,2413 & 0,1826 & 0,1826 \\
Ürün-5 & 39326 & 01639 & 7931 & 08696 & 08696 \\
\hline Toplam & 1 & 1 & 1 & 1 & 1 \\
\hline
\end{tabular}

3.3.1.5. Alternatiflerin önceliklerinin hesaplanmasl (Calculation of the priorities of the alternatives)

Alternatiflerin Öncelik Değerler Matrisi "AWx" aşağıdaki gibi oluşmaktadır. Madde 3.2.1.3. deki (Tablo 3.5. Kriterler için öncelik değerler matrisi) dikkate alındığında,

Tablo 3.27. Cihaz ağırlığına göre öncelik değerleri (Priority values according to the device weight)

\begin{tabular}{|c|c|}
\hline \multicolumn{2}{|c|}{ AWx --- Alternatifler } \\
\hline \multicolumn{2}{|c|}{ Cihaz Ă̆ırlığına Göre } \\
\hline \multicolumn{2}{|c|}{ Öncelik Değerleri } \\
\hline Ürün-1 & 0,046877146 \\
\hline Ürün-2 & 0,245389497 \\
\hline Ürün-3 & 0,497119254 \\
\hline Ürün-4 & 0,105307052 \\
\hline Ürün-5 & 0,105307052 \\
\hline TOPLAM & 1 \\
\hline
\end{tabular}


Tablo 3.28. Çift yönlü telefon görüşmesine göre öncelik değerleri

(Priority values according to the two-way telephone conversation)

\begin{tabular}{|c|c|}
\hline \multicolumn{2}{|c|}{ AWx --- Alternatifler } \\
\hline Çift Yönlü Telefon Görüşmesine Göre \\
\hline \multicolumn{2}{|c|}{ Öncelik Değerleri } \\
\hline Ürün-1 & 0,411764706 \\
\hline Ürün-2 & 0,411764706 \\
\hline Ürün-3 & 0,058823529 \\
\hline Ürün-4 & 0,058823529 \\
\hline Ürün-5 & 0,058823529 \\
\hline TOPLAM & 1 \\
\hline
\end{tabular}

Tablo 3.29. Telefon numarası kaydedebilme sayısına göre öncelik değerleri

(Priority values based on the number of telephone number recording ability)

\begin{tabular}{|c|c|}
\hline \multicolumn{2}{|c|}{ AWx } \\
\hline $\begin{array}{c}\text { Telefon Numarası Kaydedebilme } \\
\text { Sayısına Göre } \\
\text { Salternatifler }\end{array}$ \\
\hline \multicolumn{2}{|c|}{ Öncelik Değerleri } \\
\hline Ürün-1 & 0,294117647 \\
\hline Ürün-2 & 0,058823529 \\
\hline Ürün-3 & 0,294117647 \\
\hline Ürün-4 & 0,058823529 \\
\hline Ürün-5 & 0,294117647 \\
\hline
\end{tabular}

Tablo 3.30. Ortam dinleme özelliğine göre öncelik değerleri

(Priority value according to environment listening feature)

\begin{tabular}{|c|c|}
\hline \multicolumn{2}{|c|}{ AWx --- Alternatifler } \\
\hline \multicolumn{2}{|c|}{ Ortam DinlemeÖzelliğine Göre } \\
\hline \multicolumn{2}{|c|}{ Öncelik Değerleri } \\
\hline Ürün-1 & 0,411764706 \\
\hline Ürün-2 & 0,058823529 \\
\hline Ürün-3 & 0,058823529 \\
\hline Ürün-4 & 0,058823529 \\
\hline Ürün-5 & 0,411764706 \\
\hline TOPLAM & 1 \\
\hline
\end{tabular}

Tablo 3.31. LCD ekran özelliğine göre öncelik değerleri

(Priority values according according to the LCD screen feature)

\begin{tabular}{|c|c|}
\hline \multicolumn{2}{|c|}{ AWx --- Alternatifler } \\
\hline \multicolumn{2}{|c|}{ LCD Ekran Özelliğine Göre } \\
\hline \multicolumn{2}{|c|}{ Öncelik Değerleri } \\
\hline Ürün-1 & 0,636363636 \\
\hline Ürün-2 & 0,090909091 \\
\hline Ürün-3 & 0,090909091 \\
\hline Ürün-4 & 0,090909091 \\
\hline Ürün-5 & 0,090909091 \\
\hline TOPLAM & 1 \\
\hline
\end{tabular}

Tablo 3.32. Şarj olma süresine göre öncelik değerleri (Priority values according to the charging time)

\begin{tabular}{|c|c|}
\hline \multicolumn{2}{|c|}{ AWx --- Alternatifler } \\
\hline \multicolumn{2}{|c|}{ Şarj OlmaSüresine Göre } \\
\hline \multicolumn{2}{|c|}{ Öncelik Değerleri } \\
\hline Ürün-1 & 0,088568443 \\
\hline Ürün-2 & 0,088568443 \\
\hline Ürün-3 & 0,496175549 \\
\hline Ürün-4 & 0,238119122 \\
\hline Ürün-5 & 0,088568443 \\
\hline TOPLAM & 1 \\
\hline
\end{tabular}

Tablo 3.33. Kullanım süresine göre öncelik değerleri (Priority values according to the lifetime)

\begin{tabular}{|c|c|}
\hline \multicolumn{2}{|c|}{ AWx --- Alternatifler } \\
\hline $\begin{array}{c}\text { Kullanım Süresine (15dak bir veri } \\
\text { gönderme) Göre }\end{array}$ \\
\hline \multicolumn{2}{|c|}{ Öncelik Değerleri } \\
\hline Ürün-1 & 0,502819496 \\
\hline Ürün-2 & 0,034820809 \\
\hline Ürün-3 & 0,260231588 \\
\hline Ürün-4 & 0,134350441 \\
\hline Ürün-5 & 0,067777667 \\
\hline TOPLAM & 1 \\
\hline
\end{tabular}

Tablo 3.34. Haritadan izleyebilme özelliğine göre öncelik değerleri

(Priority values according to tracking on the map feature)

\begin{tabular}{|c|c|}
\hline \multicolumn{2}{|c|}{ AWx --- Alternatifler } \\
\hline Haritadan İzleyebilme Özelliğine \\
\hline \multicolumn{2}{|c|}{ Öncelik Değerleri } \\
\hline Ürün-1 & 0,2 \\
\hline Ürün-2 & 0,2 \\
\hline Ürün-3 & 0,2 \\
\hline Ürün-4 & 0,2 \\
\hline Ürün-5 & 0,2 \\
\hline TOPLAM & 1 \\
\hline
\end{tabular}

Tablo 3.35. Uzaktan cihaz ayarlarını değiştirebilme özelliğine göre öncelik değerleri

(Priority values according to remote changing of device settings feature)

\begin{tabular}{|c|c|}
\hline \multicolumn{2}{|c|}{ AWx --- Alternatifler } \\
\hline $\begin{array}{c}\text { Uzaktan Cihaz Ayarlarını } \\
\text { Değiştirebilme Özelliğine Göre }\end{array}$ \\
\hline \multicolumn{2}{|c|}{ Öncelik Değerleri } \\
\hline Ürün-1 & 0,2 \\
\hline Ürün-2 & 0,2 \\
\hline Ürün-3 & 0,2 \\
\hline Ürün-4 & 0,2 \\
\hline Ürün-5 & 0,2 \\
\hline TOPLAM & 1 \\
\hline
\end{tabular}


Tablo 3.36. GPS alıcılı kanal sayısıne göre öncelik değerleri

(Priority values by the number of GPS receiver channels)

\begin{tabular}{|c|c|}
\hline \multicolumn{2}{|c|}{ AWx } \\
\hline GPS Alıcı KanalSayısına Göre \\
\hline \multicolumn{2}{|c|}{ Öncelik Değerleri } \\
\hline Ürün-1 & 0,464290209 \\
\hline Ürün-2 & 0,095448746 \\
\hline Ürün-3 & 0,031845978 \\
\hline Ürün-4 & 0,204207533 \\
\hline Ürün-5 & 0,204207533 \\
\hline TOPLAM & 1 \\
\hline
\end{tabular}

Hem Kriterler için hemde Alternatifler için Öncelik değerleri bulunduktan sonra, belirlenen kriterlerin ağırlıkları'nın tutarlı olup olmadığını belirlemek için Tutarlılık Kontrolü yapılmalıdır.

\subsection{Tutarlılık Kontrolü (Consistency Check)}

AHP kendi içinde ne kadar tutarlı bir sistematiğe sahip olsa da sonuçların gerçekçiliği doğal olarak, karar vericinin kriterler arasında yaptığı birebir karşılaştırmadaki tutarlılığa bağlı olacaktır. AHP bu karşılaştırmalardaki tutarlılığın ölçülebilmesi için bir süreç önermektedir. Sonuçta elde edilen Tutarlılık Oranı (CR) ile bulunan öncelik vektörünün ve dolayısıyla kriterler arasında yapılan birebir karşılaştırmaların tutarlılığın test edilebilmesi imkânını sağlamaktadır. AHP, CR hesaplamasının özünü, kriter sayısı ile Temel Değer adı verilen $(\boldsymbol{\lambda})$ bir katsayının karşılaştırılmasına dayandırmaktadır. $\quad \lambda{ }^{\prime}$ nın hesaplanması için öncelikle karşılaştırma matrisi ile "W" öncelik vektörünün matris çarpımından D sütun vektörü elde edilir.

$$
D=\left[\begin{array}{cccc}
a_{11} & a_{12} & \ldots & a_{1 n} \\
a_{21} & a_{22} & \ldots & a_{2 n} \\
\cdot & & & \cdot \\
\cdot & & & \cdot \\
\cdot & & & \cdot \\
a_{n 1} & a_{n 2} & \ldots & a_{n n}
\end{array}\right]\left[\begin{array}{c}
w_{1} \\
w_{2} \\
\cdot \\
\cdot \\
\cdot \\
w_{n}
\end{array}\right]
$$

\subsubsection{Kriterler için tutarlılı kontrolünün} hesaplanmasl (Calculating the consistency check for criteria)

Kriterler için "C" Karşılaştırma Matrisi ile "CW" Öncelik Matrisisinin, matris çarpımı;

\begin{tabular}{|c|c|}
\hline \multirow{4}{*}{} & {$[\mathrm{C}] \mathrm{X}[\mathrm{CW}]$} \\
\hline \multirow{4}{*}{$\mathbf{D}=$} & 0,96693394 \\
\cline { 2 - 2 } & 0,96693394 \\
\cline { 2 - 2 } & 0,43350554 \\
\cline { 2 - 2 } & 0,96693394 \\
\cline { 2 - 2 } & 0,96693394 \\
\cline { 2 - 2 } & 0,23994096 \\
\cline { 2 - 2 } & 2,36288871 \\
\cline { 2 - 2 } & 2,36288871 \\
\cline { 2 - 2 } & 0,14802376 \\
\cline { 2 - 2 } & 0,96693394 \\
\hline
\end{tabular}

Eş. 3.1 formülünde tanımlandığ 1 gibi, bulunan $\mathrm{D}$ sütun vektörü ile $\mathrm{W}$ sütun vektörünün karşılıklı elemanlarının bölümünden her bir değerlendirme faktörüne ilişkin temel değer (E) elde edilir. Bu değerlerin aritmetik ortalaması (Eş. 3.2 formülü) ise karşılaştırmaya ilişkin temel değeri $(\lambda)$ verir.

$$
\begin{array}{r}
E_{i}=\frac{d_{i}}{w_{i}} i=1,2, \ldots, n \\
\lambda=\frac{\sum_{i=1}^{n} E_{i}}{n}(3.2)
\end{array}
$$

Buna göre; Kriterler için Eş. 3.1 ve Eş. 3.2 formülleri uygulanırsa;

\begin{tabular}{|c|c|}
\hline \multicolumn{2}{|c|}{$([\mathrm{C}] \mathrm{X}[\mathrm{CW}]) /[\mathrm{CW}]$} \\
\hline \multirow{4}{*}{$\mathbf{E}=$} & 10,38193 \\
\cline { 2 - 2 } & 10,38193 \\
\cline { 2 - 2 } & 10,14339 \\
\cline { 2 - 2 } & 10,38193 \\
\cline { 2 - 2 } & 10,38193 \\
\cline { 2 - 2 } & 10,03901 \\
\cline { 2 - 2 } & 10,4314 \\
\cline { 2 - 2 } & 10,4314 \\
\cline { 2 - 2 } & 10,10658 \\
\hline
\end{tabular}

ve

$\lambda=10,3061$

sonucu bulunur. Böylelikle Temel Değer olan " $\lambda$ " bulunmuş olur.

$\lambda$ hesaplandıktan sonra Tutarlılık Göstergesi (CI), aşağıdaki (Eş. 3.3) formülden yararlanarak hesaplanabilir.

$$
C I=\frac{\lambda-n}{n-1}
$$


Buna göre; Kriterler için Tutarlılık Göstergesini "CI" bulmak için Eş. 3.3 formülü uygulanırsa;

$\mathrm{CI}=0,03402$ bulunur
Son aşamada ise CI, Random Gösterge (RI) olarak adlandirılan ve Tablo 3.37'da gösterilen standart düzeltme değerine bölünerek (Eş 3.4 formülü) $\mathrm{CR}$ elde edilir. Tablo 3.37'da faktör sayısına karşıllk gelen değer seçilir. Örneğin 10 faktörlü bir karşılaştırmada kullanılacak RI değeri Tablo 3.37'da 1.49 olacaktır.

Tablo 3.37 Random gösterge (Random Index (RI))

\begin{tabular}{|l|l|l|l|l|l|l|l|l|l|l|l|l|l|}
\hline $\mathbf{N}$ & 1 & 2 & 3 & 4 & 5 & 6 & 7 & 8 & 9 & 10 & 11 & 12 & 13 \\
\hline $\mathbf{R I}$ & 0 & 0 & 0,58 & 0,90 & 1,12 & 1,24 & 1,35 & 1,41 & 1,45 & 1,49 & 1,51 & 1,48 & 1,56 \\
\hline
\end{tabular}

$$
C R=\frac{C I}{R I}(3.4)
$$

Buna göre; Kriterler için Tutarlılık Oranı "CR" bulmak için Eş 3.4 formülü uygulanırsa;

$\mathrm{CR}=0,02283$ bulunur.

İkili karşılaştırma yargılarının tutarlılığını ölçmek için Saaty tarafından önerilen bir tutarsızlık oranı kullanılmaktadır [15].

Tutarsızlık oranı, her ikili karşılaştırma matrisi için hesaplanmakta ve bu CR oranın 0.10 'den küçük olması istenmektedir. Kriterler için hesaplanan tutarsılılk oranı 0.10 'un altında ise kriterlerin yeterli bir tutarlılık sergilediği ve değerlendirmenin devam edebileceği kabul edilmektedir. Eğer kriterlerin tutarsızlık oranı 0.10'un üstünde ise kriterler tutarsı kabul edilmektedir. $\mathrm{Bu}$ durumda kriter değerlerinin iyileştirilmesi gerekmektedir.
Buna göre; $C R=0,02283<0,10$ olduğu için belirlenen Kriterlerin Ăğrlıklarının Tutarlı olduğu söylemek mümkündür.

Buraya kadar sadece Kriterlerin ikili karşılaştırma matrisi için Tutarlılık ölçümü yapılmıştır. Aynı şekilde Alternatiflerin Karşılaştırma Matrisleri içinde Tutarlılık testi yapılmalidir.

\subsubsection{Alternatifler için tutarlılık kontrolünün hesaplanmasl (Calculation of the consistency check for alternatives)}

Bu aşamada Başlık “3.3.1. Kriterler için tutarlılık kontrolünün hesaplanması " konusundaki formüller (Eş.3.1, Eş.3.2, Eş.3.3, Eş.3.4) belirlenen alternatiflerin değerleriiçin de aynı şekilde uygulanır.

Buna göre; Alternatifler için Tutarlılık hesaplamaları aşağıdaki gibidir.

Tablo 3.38 Cihaz ağırlığına göre tutarlılık oranı (Consistency ratio by weight of the device)

\begin{tabular}{|c|c|c|c|c|c|}
\hline Cihaz Ağırlığına Göre & {$[\mathbf{A x}] \mathbf{x}[\mathbf{A W x}]$} & $([\mathbf{A x}] \mathbf{x}[\mathbf{A W} \mathbf{W}]) /[\mathbf{A w x}]$ & $\lambda=\frac{\sum_{i=1}^{n} E_{i}}{n}$ & $C I=\frac{\lambda-n}{n-1}$ & $C R=\frac{C I}{R I}$ \\
\hline \multirow{5}{*}{$\mathbf{D}=$} & 0,237176783 & 5,059539727 & \multirow{5}{*}{5,12735293} & \multirow{5}{*}{0,031838232} & \multirow{5}{*}{0,028426993} \\
\hline & 1,277323956 & 5,205291889 & & & \\
\hline & 2,614498285 & 5,259297976 & & & \\
\hline & 0,532465892 & 5,056317521 & & & \\
\hline & 0,532465892 & 5,056317521 & & & \\
\hline
\end{tabular}

Tablo 3.39 Çift yönlü telefon görüşmesine göre tutarlılık oranı

\begin{tabular}{|c|c|c|c|c|c|}
\hline $\begin{array}{l}\text { Çift Yönlü Telefon } \\
\text { Görüşmesine Göre }\end{array}$ & {$[\mathbf{A x}] \mathbf{x}[\mathbf{A W x}]$} & $([\mathbf{A x}] \mathbf{x}[\mathbf{A W x}]) /[\mathbf{A w} \mathbf{x}]$ & $\lambda=\frac{\sum_{i=1}^{n} E_{i}}{n}$ & $C I=\frac{\lambda-n}{n-1}$ & $C R=\frac{C I}{R I}$ \\
\hline \multirow{5}{*}{$\mathbf{D}=$} & 2,058823529 & 5 & \multirow{5}{*}{5} & \multirow{5}{*}{0} & \multirow{5}{*}{$\mathbf{0}$} \\
\hline & 2,058823529 & 5 & & & \\
\hline & \begin{tabular}{|l|}
0,294117647 \\
\end{tabular} & 5 & & & \\
\hline & 0,294117647 & 5 & & & \\
\hline & 0,294117647 & 5 & & & \\
\hline
\end{tabular}


Tablo 3.40 Telefon numarası kaydedebilme özelliğine göre tutarlılık oranı

(Consistency ratio according to telephone number recording feature)

\begin{tabular}{|c|c|c|c|c|c|}
\hline $\begin{array}{c}\text { Telefon Numarası } \\
\text { Kaydedebilme Sayısına }\end{array}$ & {$[\mathbf{A x}] \mathbf{x}[\mathbf{A W x}]$} & $([\mathbf{A x}] \mathbf{x}[\mathbf{A W x}]) /[\mathbf{A w x}]$ & $\lambda=\frac{\sum_{i=1}^{n} E_{i}}{n}$ & $C I=\frac{\lambda-n}{n-1}$ & $C R=\frac{C I}{R I}$ \\
\hline \multirow{5}{*}{$\mathbf{D}=$} & 1,470588235 & 5 & \multirow{5}{*}{5} & \multirow{5}{*}{0} & \multirow{5}{*}{$\mathbf{0}$} \\
\hline & 0,294117647 & 5 & & & \\
\hline & 1,470588235 & 5 & & & \\
\hline & 0,294117647 & 5 & & & \\
\hline & 1,470588235 & 5 & & & \\
\hline
\end{tabular}

Tablo 3.41 Ortam dinleme özelliğine göre tutarlılık oranı

(Consistency ratio according to the ambient listening feature)

\begin{tabular}{|c|c|c|c|c|c|}
\hline $\begin{array}{l}\text { Ortam Dinleme } \\
\text { Özelliğine Göre }\end{array}$ & {$[\mathbf{A x}] \mathbf{x}[\mathbf{A W x}]$} & $([\mathbf{A x}] \mathbf{x}[\mathbf{A W x}]) /[\mathbf{A w x}]$ & $\lambda=\frac{\sum_{i=1}^{n} E_{i}}{n}$ & $C I=\frac{\lambda-n}{n-1}$ & $C R=\frac{C I}{R I}$ \\
\hline \multirow{5}{*}{$\mathbf{D}=$} & 2,058823529 & 5 & \multirow{5}{*}{5} & \multirow{5}{*}{0} & \multirow{5}{*}{$\mathbf{0}$} \\
\hline & 0,294117647 & 5 & & & \\
\hline & 0,294117647 & 5 & & & \\
\hline & 0,294117647 & 5 & & & \\
\hline & 2,058823529 & 5 & & & \\
\hline
\end{tabular}

Tablo 3.42 LCD ekran özelliğine göre göre tutarlılık oranı

\begin{tabular}{|c|c|c|c|c|c|}
\hline \multicolumn{6}{|c|}{ (Consistency rate than by LCD screen feature) } \\
\hline $\begin{array}{c}\text { LCD Ekran Özelliğine } \\
\text { Göre }\end{array}$ & {$[\mathbf{A x}] \mathbf{x}[\mathbf{A W x}]$} & $([\mathbf{A x}] \mathbf{x}[\mathbf{A W x}]) /[\mathbf{A w x}]$ & $\lambda=\frac{\sum_{i=1}^{n} E_{i}}{n}$ & $C I=\frac{\lambda-n}{n-1}$ & $C R=\frac{C I}{R I}$ \\
\hline \multirow{5}{*}{$\mathbf{D}=$} & 3,181818182 & 5 & \multirow{5}{*}{5} & \multirow{5}{*}{0} & \multirow{5}{*}{$\mathbf{0}$} \\
\hline & 0,454545455 & 5 & & & \\
\hline & 0,454545455 & 5 & & & \\
\hline & 0,454545455 & 5 & & & \\
\hline & 0,454545455 & 5 & & & \\
\hline
\end{tabular}

Tablo 3.43 Şarj olma süresine göre tutarlılık oranı (Consistency ratio by charging time)

\begin{tabular}{|c|c|c|c|c|c|}
\hline $\begin{array}{c}\text { Şarj Olma Süresine } \\
\text { Göre }\end{array}$ & {$[\mathbf{A x}] \mathbf{x}[\mathbf{A W x}]$} & $([\mathbf{A x}] \mathbf{x}[\mathbf{A W x}]) /[\mathbf{A w x}]$ & $\lambda=\frac{\sum_{i=1}^{n} E_{i}}{n}$ & $C I=\frac{\lambda-n}{n-1}$ & $C R=\frac{C I}{R I}$ \\
\hline \multirow{5}{*}{$\mathbf{D}=$} & 0,44431348 & 5,016611609 & \multirow{5}{*}{5,04184456} & \multirow{5}{*}{0,010461141} & \multirow{5}{*}{0,009340304} \\
\hline & 0,44431348 & 5,016611609 & & & \\
\hline & 2,539059561 & 5,117260551 & & & \\
\hline & 1,200626959 & 5,042127435 & & & \\
\hline & 0,44431348 & 5,016611609 & & & \\
\hline
\end{tabular}

Tablo 3.44 Kullanım süresine göre tutarlılık oranı (Consistency ratio by the lifetime)

\begin{tabular}{|c|c|c|c|c|c|}
\hline $\begin{array}{l}\text { Kullanım Süresine } \\
\text { (15dak bir veri } \\
\text { gönderme) Göre }\end{array}$ & {$[\mathbf{A x}] \mathbf{x}[\mathbf{A W x}]$} & $([\mathbf{A x}] \mathbf{x}[\mathbf{A W} \mathbf{x}]) /[\mathbf{A w x}]$ & $\lambda=\frac{\sum_{i=1}^{n} E_{i}}{n}$ & $C I=\frac{\lambda-n}{n-1}$ & $C R=\frac{C I}{R I}$ \\
\hline \multirow{5}{*}{80} & 2,743097411 & 5,455431689 & \multirow{5}{*}{5,24260692} & \multirow{5}{*}{0,060651729} & \multirow{5}{*}{$\mathbf{0 , 0 5 4 1 5 3 3 3}$} \\
\hline & 0,177328227 & 5,09259353 & & & \\
\hline & 1,413523405 & 5,431790266 & & & \\
\hline & 0,699095248 & 5,203520323 & & & \\
\hline & 0,340901248 & 5,029698779 & & & \\
\hline
\end{tabular}


Tablo 3.45 Haritadan izleyebilme özelliğine göre tutarlılık oranı

\begin{tabular}{|c|c|c|c|c|c|}
\hline \multicolumn{6}{|c|}{ (Consistency ratio by tracking on the map feature) } \\
\hline $\begin{array}{l}\text { Haritadan İzleyebilme } \\
\text { Özelliğine Göre }\end{array}$ & {$[\mathbf{A x}] \mathbf{x}[\mathbf{A} \mathbf{W} \mathbf{x}]$} & $([\mathbf{A x}] \mathbf{x}[\mathbf{A W x}]) /[\mathbf{A w x}]$ & $\lambda=\frac{\sum_{i=1}^{n} E_{i}}{n}$ & $C I=\frac{\lambda-n}{n-1}$ & $C R=\frac{C I}{R I}$ \\
\hline \multirow{5}{*}{$\mathbf{D}=$} & 1 & 5 & \multirow{5}{*}{5} & \multirow{5}{*}{0} & \multirow{5}{*}{$\mathbf{0}$} \\
\hline & 1 & 5 & & & \\
\hline & 1 & 5 & & & \\
\hline & 1 & 5 & & & \\
\hline & 1 & 5 & & & \\
\hline
\end{tabular}

Tablo 3.46 Uzaktan cihaz ayarlarını değiştirebilme özelliğine göre tutarlılık oranı

\begin{tabular}{|c|c|c|c|c|c|}
\hline $\begin{array}{c}\text { Uzaktan Cihaz } \\
\text { Ayarlarını } \\
\text { Değiştirebilme }\end{array}$ & {$[\mathbf{A x}] \mathbf{x}[\mathbf{A W x}]$} & $([\mathbf{A x}] \mathbf{x}[\mathbf{A W} \mathbf{W}]) /[\mathbf{A} \mathbf{w} \mathbf{x}]$ & $\lambda=\frac{\sum_{i=1}^{n} E_{i}}{n}$ & $C I=\frac{\lambda-n}{n-1}$ & $C R=\frac{C I}{R I}$ \\
\hline \multirow{5}{*}{$\mathbf{D}=$} & 1 & 5 & \multirow{5}{*}{5} & \multirow{5}{*}{0} & \multirow{5}{*}{$\mathbf{0}$} \\
\hline & 1 & 5 & & & \\
\hline & 1 & 5 & & & \\
\hline & 1 & 5 & & & \\
\hline & 1 & 5 & & & \\
\hline
\end{tabular}

Tablo 3.47 GPS alıcı kanal sayısına göre tutarlılık oranı

(Consistency ratio by the number of GPS receiver channel)

\begin{tabular}{|c|c|c|c|c|c|}
\hline $\begin{array}{l}\text { GPS Alıcı Kanal } \\
\text { Sayısına Göre }\end{array}$ & {$[\mathbf{A x}] \mathbf{x}[\mathbf{A} \mathbf{W} \mathbf{x}]$} & $([\mathbf{A x}] \mathbf{x}[\mathbf{A W x}]) /[\mathbf{A w x}]$ & $\lambda=\frac{\sum_{i=1}^{n} E_{i}}{n}$ & $C I=\frac{\lambda-n}{n-1}$ & $C R=\frac{C I}{R I}$ \\
\hline \multirow{5}{*}{$\mathbf{D}=$} & 2,453392943 & 5,284179798 & \multirow{5}{*}{5,18130227} & \multirow{5}{*}{0,045325567} & \multirow{5}{*}{0,040469256} \\
\hline & 0,483675033 & 5,06737963 & & & \\
\hline & 0,160868538 & 5,05145542 & & & \\
\hline & 1,072446554 & 5,251748242 & & & \\
\hline & 1,072446554 & 5,251748242 & & & \\
\hline
\end{tabular}

Buna göre; $y u k a r l d a k i$ tablolarda görüldüğü gibi Alternatiflerin Tutarlılık oranlarının hepsi 0.10 değerinden küçük çıkmıştır. Bu durumda alternatifler için kullanılan değerlerin bütünüyle Tutarlı olduğu söylenebilir.

3.5. Her Bir Faktör İçin, $m$ Karar Noktasındaki Yüzde Önem Dă̆llımları Bulunur (For each factor, is Important to Find Percent Distribution in $m$ Decision Point)

Şimdiye kadar hesapladığımız öncelik değer matrislerini birleştirerek her bir kriter için, alternatiflerin yüzde önem dağılımları bulunmuş olur. Başlik "3.2.2.3. Alternatiflerin Önceliklerinin Hesaplanması" konusundaki matrislerin birleşimi aşağıdaki gibidir.

Yani [AWx]'lerin birleşim matrisi;

Tablo 3.48 Öncelik değerleri matrisi (Priority values matrix)

\begin{tabular}{|c|c|c|c|c|c|c|c|c|c|c|}
\hline \multicolumn{11}{|c|}{ Alternatifler } \\
\hline \multicolumn{11}{|c|}{ Öncelik Değerleri Matrisi } \\
\hline & 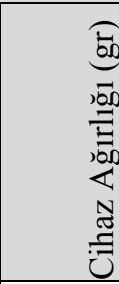 & 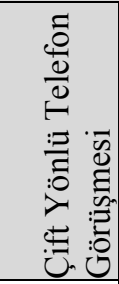 & 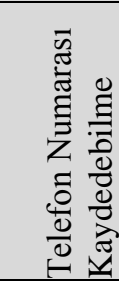 & 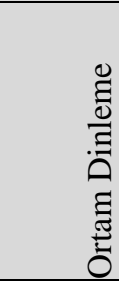 & 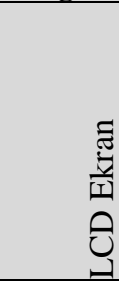 & 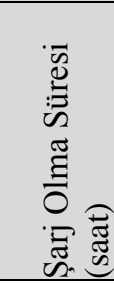 & 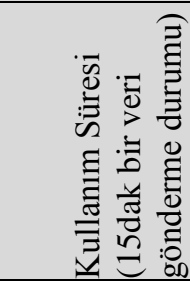 & 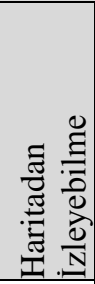 & 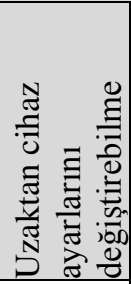 & 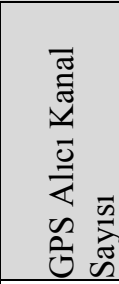 \\
\hline Ürün-1 & \begin{tabular}{|l|}
0,0468 \\
77146
\end{tabular} & $\begin{array}{l}0,4117 \\
64706\end{array}$ & \begin{tabular}{|c|}
0,2941 \\
17647
\end{tabular} & $\begin{array}{l}0,4117 \\
64706\end{array}$ & \begin{tabular}{|c|}
0,6363 \\
63636
\end{tabular} & $\begin{array}{l}0,0885 \\
68443\end{array}$ & $\begin{array}{c}0,50281949 \\
6\end{array}$ & 0,2 & 0,2 & $\begin{array}{l}0,4642 \\
90209\end{array}$ \\
\hline Ürün-2 & \begin{tabular}{|l|}
0,2453 \\
89497
\end{tabular} & $\begin{array}{l}0,4117 \\
64706\end{array}$ & \begin{tabular}{|l|}
0,0588 \\
23529 \\
\end{tabular} & $\begin{array}{l}0,0588 \\
23529\end{array}$ & \begin{tabular}{|c|}
0,0909 \\
09091
\end{tabular} & $\begin{array}{l}0,0885 \\
68443\end{array}$ & $\begin{array}{c}0,03482080 \\
9\end{array}$ & 0,2 & 0,2 & $\begin{array}{l}0,0954 \\
48746\end{array}$ \\
\hline
\end{tabular}




\begin{tabular}{|c|c|c|c|c|c|c|c|c|c|c|}
\hline Ürün & $\begin{array}{c}0,4971 \\
19254\end{array}$ & $\begin{array}{l}0,0588 \\
23529\end{array}$ & $\begin{array}{c}0,2941 \\
17647\end{array}$ & \begin{tabular}{|l|}
0,0588 \\
23529
\end{tabular} & $\begin{array}{c}0,0909 \\
09091\end{array}$ & $\begin{array}{l}0,4961 \\
75549\end{array}$ & $\begin{array}{c}0,26023158 \\
8\end{array}$ & 0,2 & 0,2 & \begin{tabular}{|c|}
0,0318 \\
45978
\end{tabular} \\
\hline Ürür & $\begin{array}{l}0,1053 \\
07052\end{array}$ & $\begin{array}{l}0,0588 \\
23529\end{array}$ & $\begin{array}{l}0,0588 \\
23529\end{array}$ & $\begin{array}{l}0,0588 \\
23529\end{array}$ & $\begin{array}{c}0,0909 \\
09091\end{array}$ & $\begin{array}{l}0,2381 \\
19122\end{array}$ & $\begin{array}{c}0,13435044 \\
1\end{array}$ & 0,2 & 0,2 & $\begin{array}{c}0,2042 \\
07533\end{array}$ \\
\hline Ürün-5 & $\begin{array}{c}0,1053 \\
07052\end{array}$ & $\begin{array}{l}0,0588 \\
23529\end{array}$ & $\begin{array}{l}0,2941 \\
17647\end{array}$ & $\begin{array}{l}0,4117 \\
64706\end{array}$ & $\begin{array}{l}0,0909 \\
09091\end{array}$ & $\begin{array}{c}0,0885 \\
68443\end{array}$ & $\begin{array}{c}0,06777766 \\
7\end{array}$ & 0,2 & 0,2 & $\begin{array}{c}0,2042 \\
07533\end{array}$ \\
\hline
\end{tabular}

3.6. Karar Noktalarındaki Sonuç Dă̆gllımının Bulunmasl (Determining the result Distribution on the Decision Points)

AHP'nin son aşaması, karar probleminin çözümlenmesi aşamasıdır. $\mathrm{Bu}$ aşamada problemin ana hedefinin gerçekleştirilmesinde karar alternatiflerinin sıralaması olarak hizmet edecek bir karma öncelikler vektörü oluşturulur. $\mathrm{Bu}$ vektörü oluşturmak için her değişken için belirlenen öncelik vektörlerinin ağırlıklı ortalaması alınır [16].

Bu aşamada Başlık "3.4. Her Bir Faktör İçin, m Karar Noktasındaki Yüzde Önem Dağılımları Bulunur" konusundaki Alternatiflerin Öncelik Değerleri Matrisi ile Başlık "3.2.1.3. Kriterlerin Önceliklerinin Hesaplanması" konusundaki Kriterler Öncelik Değerleri Matrisinin Matris Çarpımı ile Sonuç Matrisi elde edilmektedir.

Yani $[\mathrm{AWx}$ ] ile [CW] matrislerinin Matris çarpımı sonucu aşağıdaki gibidir.

Alternatif Öncelik Değerleri Matrisi X Kriterler Öncelik Değerleri Matrisi

\begin{tabular}{|c|c|c|}
\hline \multicolumn{3}{|c|}{ SONUÇ (CONCLUSION) } \\
\hline Ürün - 1 & 0,360393732 & $\mathbf{1}$ \\
\hline Ürün - 2 & 0,144791139 & $\mathbf{3}$ \\
\hline Ürün - 3 & 0,200298432 & $\mathbf{2}$ \\
\hline Ürün - 4 & 0,135121698 & $\mathbf{5}$ \\
\hline Ürün - 5 & 0,159394998 & $\mathbf{4}$ \\
\hline
\end{tabular}

\section{Bu sonuca göre;}

Ürün - 1 1.öncelikli satın alınması gereken Marka Ürün - 3 2.öncelikli satın alınması gereken Marka Ürün - 2 3.öncelikli satın alınması gereken Marka Ürün - 5 4.öncelikli satın alınması gereken Marka Ürün - 4 5.öncelikli satın alınması gereken Marka

\section{SONUÇ (CONCLUSION)}

Kişi takip cihazları, sevdiklerimizle iletişimimizi koparmamak ve zor anlarında yanında olabilmek için kritik öneme sahiptir. Son yıllarda yeni gelişmekte olan kişi takip cihazlarının, teknoloji tabanlı bileşenlerden oluştuğu düşünüldüğünde teknoloji hızıyla paralel bir gelişme süreci geçirdiği söylenebilir.
Teknolojinin değişim ve gelişim hızına bağlı olarak mevcut piyasada farklı özelliklere sahip birçok kişi takip cihazı bulunmaktadır. $\mathrm{Bu}$ durumda birçok seçenek arasında istek ve ihtiyaçları karşılayabilecek en uygun kişi takip cihazı seçimi probleminin önemi ortaya çıkmaktadır. Böyle bir seçim probleminde, sezgilerimize güvenmek veya çevreden aldığımız kullanıcı bildirimlerinden ziyade bilimsel bir yaklaşım olan Analitik Hiyerarşi Süreci uygulamasının doğru karar vermemize yardımcı olacağı düşünülmektedir.

Bu çalışmada, kişi takip cihazı üreten 5 farklı firmaya ait 5 farklı ürün kişi takip cihazlarının piyasa özellikleri dikkate alınarak belirlenen on adet kriter kapsamında değerlendirilmiştir. Belirlenen alternatifler ve kriterler analitik hiyerarşi sürecine göre irdelenmiştir. Sırasıyla alternatiflerin ve kriterlerin ikili karşılaştırma matrisleri, normalizasyonları, öncelik değerleri hesaplanmıştır. Kriterler ve alternatifler için ayrı ayrı hesaplanan öncelik değerlerine matris çarpımı uygulayarak alternatiflerin kriterlere göre öncelik değerleri hesaplanmıştır. Böylelikle uygulanan yöntemin adımları sonucunda, alternatifler arasında kullanıcı istek ve ihtiyaçlarını en iyi karşılayan kişi takip cihazının Ürün 1 olduğu belirlenmiştir.

İnsanlık tarihi boyunca, herhangi bir seçim yaparken insan istek ve ihtiyaçlarının bireyden bireye değişiklik gösterdiği görülmektedir. $\mathrm{Bu}$ durumda çalışmada yer alan kişi takip cihazı seçiminde istenilen cihaz özelliklerinin de kişiden kişiye değişiklik gösterebileceği son derece doğal bir durumdur. Çalışmada belirlenen kriterler ve alternatiflere verilen değerlerin farklı karar vericiler tarafindan değerlendirilmesi durumunda bulgularında değişebileceği unutulmaması gereken önemli bir nokta olarak düşünülmelidir.

\section{KAYNAKLAR (REFERENCES)}

[1] T. Harcar, "Silahlı Kuvvetlerde Karar Verme 1 nci Baskı”, K.H.O Yayınları, Ankara, 9-12 (1992).

[2] B.J.R. Harold, "Quantitative Analysis for Business Decisions 4th Edition", Richard D.Irwin Inc. Homewood, illionis, 19 (1973).

[3] J.A.F. Stoner, ve , R.E. Freeman, "Management 2nd Edition", Printice Hall, New Jersey, 37-39 (1989). 
[4] R. Evren, ve K. Ülengin, "Yönetimde Karar Verme 1.nci Baskı", ITÜ Yayınları, 1478 (1992).

[5] B.A. Himmetoğlu, "Karar Verme Yeteneğini Geliştirme 3 ncü Baskı”, Karınca Yayınları, İzmir, 2325 (1971).

[6] X. Wang, E. Triantaphyllou, "Ranking irregularities when evaluating alternatives by using some ELECTRE methods", Omega, 36, 45 - 63 (2008).

[7] W. Ho, "Integrated analytic hierarchy process and its applications-A literature review", European Journal of Operational Research, 186, 211-228 (2008).

[8] R. A. Taha, T. Daim "Multi-Criteria Applications in Renewable Energy Analysis, a Literature Review", Research and Technology Management in the Electricity Industry Green Energy and Technology, pp 17-30 (2013).

[9] Z.G. Göktolga, B. Gökalp, “İş seçimini etkileyen kriterlerin ve alternatiflerin AHP metodu ile belirlenmesi", C. ̈̈. Íktisadi ve İdari Bilimler Dergisi, Cilt 13, Sayı 2, (2012).

[10] A. Güngör, G. Serhadlıoğlu, S.E. Kesen "A fuzzy AHP approach to personnel selection problem", Applied Soft Computing, 9, 641-646 (2009).
[11] A. Ishizaka, A. Labib, "Selection of new production facilities with the Group Analytic HierarchyProcess Ordering method", Expert Systems with Application 38, 7317-7325(2011).

[12] J.L. Garcia, A. Alvarado, J. Blanco, E. Jimenez, A.A. Maldonado, G. Cortes, "Multi-attribute evaluation and selection of sites for agricultural productwarehouses based on an Analytic Hierarchy Process", Computers and Electronics in Agriculture 100, 60-69 (2014).

[13] M.S. Garcia-Cascales, M.T. Lamata, "Selection of a cleaning system for engine maintenance based on the analytichierarchy process", Computers \& Industrial Engineering 56, 1442-1451 (2009).

[14] A. Karaüzüm, N. Atsan, "Analitik hiyerarşi yöntemi ve işletmecilik alanındaki uygulamaları", Akdeniz I.I. B.F. Dergisi, 1(1) 83-105 (2001).

[15] T. L. Saaty, "The Analytic Hierarchy Process 4th Edition", McGraw-Hill Book Co., New York, 9-126 (1980).

[16] F. Zahedi, "A simulation study of estimation methods in the analytic hierarchy process", SocioEconomic Planning Sciences, 20: 347-354 (1986). 